PIOTR ŁOZOWSKI

Instytut Historii i Nauk Politycznych Uniwersytetu w Białymstoku

\title{
STRUKTURA RYNKU KREDYTOWEGO STAREJ WARSZAWY W LATACH 1427-1453
}

Zarys treści: Artykuł przedstawia wyniki analiz funkcjonowania rynku kredytowego Starej Warszawy w drugiej ćwierci XV stulecia. W badaniach wykorzystano materiał zawarty w najstarszej z zachowanych księdze ławy miejskiej $\mathrm{z}$ lat 1427-1453. Zgromadzone dane zostały zaprezentowane za pomoca licznych wykresów i tabel. Obserwacji poddano takie elementy charakteryzujace rynek kredytowy, jak: dynamika zapisów, ich wartość, czas trwania umów, sezonowość wpisów, działanie systemu ratalnego oraz sposoby zabezpieczenia kontraktów.

The content outline: The paper presents the results of the analyses of the loan market in Old Warsaw in the second quarter of the $15^{\text {th }}$ century. The research is based on source material from the oldest of the preserved municipal court records from the years 1427-1453. The compiled data is presented with the use of a number of graphs and tables. The analysis focuses on such characteristics of the loan market as: frequency of entries, their value, duration of agreements, seasonality of entries, functioning of the instalment system, and types of collateral.

Słowa kluczowe: miasto średniowieczne, rynek kredytowy, Stara Warszawa, historia gospodarcza

Keywords: medieval town, loan market, Old Warsaw, economic history

Wiele czasu upłynęło, nim pieniądz ostatecznie i powszechnie został zaakceptowany przez ludzi średniowiecza ${ }^{1}$. Katalizatorem tych zmian

${ }^{1} \mathrm{~K}$. Olendzki, Moralność $i$ kredyt. Kontrakt kupna-sprzedaży w traktatach uczonych środkowoeuropejskich z przełomu XIVi XV wieku, „Roczniki Dziejów Społecznych i Gospodarczych" (dalej: RDSG) 56/57, 1996/1997, s. 29-67; J. Le Goff, Średniowiecze $i$ pieniadze, tłum. B. Baran, Warszawa 2011, s. 32-34, 168-172; tenże, Sakiewka 
była postępująca od XIII w. dynamiczna akcja kolonizacyjna i lokacyjna, które to wraz z rozpowszechnieniem prawa niemieckiego wpłynęły na wzrost komercjalizacji życia gospodarczego ${ }^{2}$. Jednym z jej najważniejszych elementów były miasta, których gospodarki opierały się o podział pracy oraz wymianę usług i towarów przy użyciu pieniądza monetarnego. W sytuacjach jego niedoboru pojawiał się pożyczkodawca $\mathrm{z}$ niezbędnym instrumentem, jakim był kredyt. Wielokrotnie krytykowany jako lichwiarz, sprzedawca czasu, który należał przecież do Boga ${ }^{3}$, ostatecznie jednak został zaakceptowany przez Kościół i dopuszczony do swej działalności, ale pod warunkiem m. in. nieprzekraczalnej (oficjalnie) granicy 10\% „godziwego” zysku4. Majac na uwadze powszechne w dużych i postępujace w małych miastach upieniężnie gospodarki, problem rynku kredytowego należy więc do fundamentalnych zagadnień ekonomicznych późnego średniowiecza.

Historiografia polska doczekała się szeregu mikrostudiów nad rynkiem kredytowym w XIV-XV w. Ograniczone zainteresowanie tą tematyka ${ }^{5}$ może dziwić $\mathrm{w}$ kontekście wagi zagadnienia i obfitości

$i \dot{z} y c i e$, tłum. H. Zaremska, Gdańsk 1995, s. 9-38; A. J. Guriewicz, Kupiec, w: Człowiek średniowiecza, tłum. M. Radożycka-Paoletti, Warszawa-Gdańsk 1996, s. 305-310.

2 S. Gawlas, Komercjalizacja jako mechanizm europeizacji peryferii na przyktadzie Polski, w: Ziemie polskie wobec Zachodu. Studia nad rozwojem średniowiecznej Europy, red. S. Gawlas, Warszawa 2006, s. 94-116.

3 J. Le Goff, Sakiewka..., s. 49.

4 Tenże, Średniowiecze..., s. 80-95; K. Olendzki, dz. cyt., s. 30 n.; A.J. Guriewicz, dz. cyt., s. 311-317. Dotyczyło to chrześcijan kredytodawców, Żydów obowiązywało odrębne ustawodawstwo dopuszczające pobieranie 108\% w skali rocznej, zob. M. Goliński, Wrocławskie spisy zastawów, długów i mienia żydowskiego z 1453 roku. Studium $z$ historii kredytu i kultury materialnej, Wrocław 2006, s. 23-35; B. Lesiński, Kupno renty w średniowiecznej Polsce, Poznań 1966, s. 64-82, 257-287.

${ }^{5}$ W przeciwieństwie chociażby do nauki niemieckiej, która już od XIX w. wykazywała szersze zainteresowanie tym tematem. Największe osiagnięcia w tej dziedzinie wiążą się z osobą Rolfa Sprandela i jego uczniów, którzy w latach 80. ubiegłego stulecia uformowali własną szkołę metodologiczna; zob. najnowszy przegląd badań niemieckich: C. Kardasz, Rynek kredytu pieniężnego w miastach południowego pobrzeża Battyku w późnym średniowieczu (Greifswald, Gdańsk, Elblag, Toruń, Rewel), Toruń 2013, s. 19-22. Temat kredytu podejmowali także niedawno badacze holenderscy: J.L. van Zanden, J. Zuijderduij, T. de Moor, Small is beautifull: the efficiency of credit markets in the late medieval Holland, EREH, t. 16, 2012, s. 3-22; J. Zuijderduij, Medieval Capital Markets. Markets for Renten, State Formation and Private Investment in Holland (1300-1550), Leiden-Boston 2009; W nauce anglosaskiej należy zwrócić uwagę na najważniejsze prace: M. Postan, Medieval Trade and Finance, Cambridge 1973; tenże, The Medieval Economy and Society: An Economic History of Britain 1100-1500, Cambridge 1972; R. de Roover, Money, Banking And Credit In Medieval Bruges, Cambridge 1948; P. Spufford, Money and its Use in Medieval Europe, Cambridge 1988; P. Nightingale, Gold, credit, and mortality: distinguishing deflationary pressures on 
zachowanych późnośredniowiecznych rejestrów sądowych, stanowiących główne źródło informacji ${ }^{6}$. Ponadto brak zastosowania jednolitego systemu pytań badawczych, doboru terytorialnego przedmiotu obserwacji i często dość selektywne podejście autorów do tematu znacznie utrudnia ujęcie komparatystyczne, które jest niezbędnym elementem wszelkich analiz gospodarczych.

Prace poruszające zagadnienie pożyczki w późnym średniowieczu można podzielić na dwie grupy: pierwsza obejmuje działalność szlachty, chłopów i Żydów na kredytowym rynku wiejskim, zaś druga bezpośrednio dotyczy rynków miejskich. Pomimo niesłabnącej popularności miasta jako obiektu badawczego, polscy historycy więcej uwagi poświęcili szczegółowym analizom rynku wiejskiego ${ }^{7}$. Obserwacje gospodarki miejskiej prowadzone były głównie na podstawie materiałów pochodzących z miast pruskich jako ośrodków o lepiej zachowanej bazie źródłowej $^{8}$ oraz wyższym poziomie rozwoju ekonomicznego niż większość civitates z terenów Królestwa Polskiego i Księstwa Mazowieckiego. Okres zainteresowania kredytem wśród historyków zajmujących się miastem średniowiecznym otwierają w latach 60 . XX w. prace Henryka

the late medieval English economy, EHR, t. 63, 2010, nr 4, s. 1081-1104. Podsumowanie wieloletnich dyskusji nad kryzysem gospodarczym późnego średniowiecza przedstawił ostatnio P. Guzowski, Kryzys gospodarczy późnego średniowiecza w najnowszej historiografii angielskiej, w: Przeglad badań nad historia gospodarcza $w$ XXI wieku, red. R. Matera, A. Pieczewski, Łódź 2011, s. 235-246.

${ }^{6}$ H. Samsonowicz, Średniowieczne księgi sadowe matych miast w Polsce, w: Homines et societas. Czasy Piastów i Jagiellonów, Poznań 1997, s. 477-484; J. Tandecki, Średniowieczne księgi wielkich miast pruskich jako źródła historyczne i zabytki kultury mieszczańskiej (organizacja władz, zachowane archiwalia, działalność kancelarii), Warszawa-Toruń 1990.

${ }^{7}$ M. Ungeheuer, Stosunki kredytowe $w$ ziemi przemyskiej $w$ połowie $X V$ wieku, Lwów 1929; A. Rutkowski, Warszawski rynek kredytowy (zasięg i charakterystyka), w: Warszawa Średniowieczna, red. A. Gieysztor, z. 2, Warszawa 1974, s. 69-81. Autor skupił się na sytuacji, w której miasto było wierzycielem wsi, a zatem faktycznie dotyczył on zaledwie niewielkiego wycinka (7-8\%) całego ziemskiego ruchu kredytowego; tenże, Kredyt żydowski na rynku lokalnym Warszawy w pierwszej połowie XV wieku, PH, t. 70, 1979, z. 2, s. 267-284; M. Urbański, Niektóre problemy ruchu kredytowego w ziemi sanockiej $w X V$ w., PH, t. 70, 1979, z. 4, s. 627-651; Z. Morawski, Ziemia, urzędy, pieniqdze. Finanse szlachty tęczyckiej w końcu XIV i pierwszej połowie XV wieku, Warszawa 1993; J. Karczewska, Stosunki kredytowe na terytorium Kujaw $i$ wschodniej Wielkopolski $w$ XV wieku, w: Rynki lokalne i regionalne $w$ XV-XVIII wieku, red. P. Guzowski, K. Boroda, Białystok-Kraków 2013, s. 9-18; P. Guzowski, Chłopi i pieniadze na przełomie średniowiecza i czasów nowożytnych, Kraków 2008.

${ }^{8}$ Wartość materiału pruskiego podkreślał J. Tandecki, dz. cyt., passim; tenże, Rachunkowość $i$ ksiegi rachunkowe miast pruskich $w$ średniowieczu. Wstęp do problematyki, RDSG 70, 2010, s. 19-29. 
Samsonowicza ${ }^{9}$. Powrót do tematyki badań społeczno-gospodarczych nad miastami hanzeatyckimi następuje dopiero po dwóch dekadach ${ }^{10}$. Najnowszą zaś praca poruszajaca interesujące nas zagadnienie jest niezwykle szczegółowe, obfite w dane liczbowe i oparte na szerokim spojrzeniu komparatystycznym studium Cezarego Kardasza podejmujące tematykę rynku rentowego w miastach południowego pobrzeża Bałtyku w XIV$\mathrm{XV}$ w. ${ }^{11}$ Uwagę miejskiej problematyce kredytowej poświęciła także Urszula Sowina, skupiajac się na funkcjonowaniu rynku kredytowego w niewielkim Sieradzu w XV w. ${ }^{12}$, oraz Agnieszka Bartoszewicz przy socjotopograficznych analizach społeczeństwa późnośredniowiecznej Warty ${ }^{13}$.

Warto wspomnieć, iż zagadnienie ruchu pożyczkowego bywa niekiedy przywoływane na marginesie prac w sposób ogólny traktujących o historii społeczno-gospodarczej wybranego ośrodka lub regionu ${ }^{14}$, lecz najczęściej

${ }^{9}$ H. Samsonowicz, Studia nad renta miejska $w$ Prusach $w$ XV wieku, „Zapiski Historyczne" (dalej: ZH) 25, 1960, z. 2, s. 35-57; tenże, Badania nad kapitałem mieszczańskim Gdańska w II połowie XV wieku, Warszawa 1960; tenże, Local credit in mediaeval Poland, „Studia Historiae Oeconomicae” 21, 1994, s. 51-57.

${ }_{10}$ R. Czaja, Rynek kupna renty $w$ Elblagu $w$ pierwszej połowie XIV wieku, ZH 52, 1987, z. 3, s. 7-37; tenże, Kredyt pieniężny w Starym Mieście Toruniu do roku 1410, RDSG 49, 1988, s. 5-19.

${ }^{11}$ C. Kardasz, Rynek kredytu...; tenże, Rynek kupna renty $w$ Elblagu $w$ latach 1361-1417, „Komunikaty Mazursko-Warmińskie” 261, 2008, nr 3, s. 299-318; tenże, Rady miast nadbattyckich na rynku renty $w$ XIV i pierwszej połowie XV w., RDSG 70, 2010, s. 113-145; R. Czaja, C. Kardasz, Obrót nieruchomościami i kupno renty w miastach pruskich $w X I V-X V$ w., w: Obrót nieruchomościami na ziemiach polskich od średniowiecza do XXI wieku, red. F. Kusiak, Poznań-Wrocław 2008, s. 43-50.

${ }^{12}$ U. Łydkowska-Sowina, Ruch kredytowy w późnośredniowiecznym Sieradzu - pożyczki pieniężne, w: Szkice z dziejów materialnego bytowania społeczeństwa polskiego, red. M. Dembińska, Wrocław 1989, s. 119-135.

${ }^{13}$ A. Bartoszewicz, Warta. Społeczeństwo miasta w II połowie XV i na poczatku XVI wieku, Warszawa 1997, s. 117-130.

${ }^{14}$ Spośród wielu prac należy wymienić: H. Samsonowicz, Badania nad kapitatem..., s. 69-84; A. Jelicz, Życie codzienne w średniowiecznym Krakowie, Warszawa 1966, s. 99-119; M. Bogucka, H. Samsonowicz, Dzieje miast i mieszczaństwa w Polsce przedrozbiorowej, Wrocław 1986, s. 168-200; H. Samsonowicz, Życie miasta średniowiecznego, Poznań 2001, s. 73-91; K. Kopiński, Gospodarcze i społeczne kontakty Torunia z Wrocławiem w późnym średniowieczu, Toruń 2005, s. 133-183; G. Myśliwski, Wrocław w przestrzeni gospodarczej Europy (XIII-XV wiek). Centrum czy peryferie?, Wrocław 2009, s. 232-495; M. Goliński, W poszukiwaniu motywów sprzedaży rent nowych - przykład XIV-wiecznej Świdnicy, w: Miasta i mieszczaństwo w Europie środkowowschodniej do połowy XIX w., red. D. Michaluk, K. Mikulski, Toruń 2003, s. 321-332; tenże, Wrocławskie...; tenże, Zmiany w budżecie Wroctawia $w X I V-X V w$. (w świetle bieżacego stanu badań), RDSG 70, 2010, s. 33-62; I. Janosz-Biskupowa, Materiaty do dziejów lichwy w Prusach Krzyżackich w pot. XV wieku, „Studia i Materiały do Dziejów Wielkopolski i Pomorza” 4, 1958, z. 1, s. 355-372. 
wiąże się to z zastapieniem szczegółowej i wielostronnej analizy zabiegiem egzemplifikacji, np. zaciagniętych pożyczek, kupionych rent lub zawartych przez poszczególnych mieszczan umów handlowych. Utrudnia to niestety przeprowadzenie analizy porównawczej, co sygnalizowali wszyscy autorzy monograficznych studiów nad rynkiem kredytowym ${ }^{15}$.

Prace podejmujące sensu stricto funkcjonowanie rynku pożyczkowego stanowią niewielki procent dorobku polskiej mediewistyki. Podobną uwagę należy odnieść również do badań nad późnośredniowieczną Warszawa, która wciąż nie doczekała się kompletnego opracowania miejskiego rynku kredytowego ${ }^{16}$. Jest to szczególnie zaskakujące, gdyż Stara i Nowa Warszawa w XV i początkach XVI w. ze względu na swój dynamiczny rozwój stanowi niezwykle cenny obiekt obserwacji. Zagłębiając się w dzieje gospodarki warszawskiej w epoce

${ }_{15}$ M. Urbański, dz. cyt., s. 627; A. Rutkowski, Warszawski rynek..., s. 69; tenże, Kredyt żydowski..., s. 267; R. Czaja, Kredyt pieniężnyu..., s. 5 i n; Z. Morawski, dz. cyt., s. 7 i n.; C. Kardasz, Rynek kredytu..., s. 23.

${ }_{16}$ Pierwszymi pracami poruszajacymi to zagadnienie od strony kwantytatywnej są badania A. Rutkowskiego - oprócz wspomnianych artykułów (zob. przyp. 7) także nieopublikowany doktorat: A. Rutkowski, „Więzi kredytowe Warszawy w I połowie XV wieku”, Warszawa 1975, ss. 117 (maszynopis pracy doktorskiej znajduje się w Bibliotece Instytutu Historii PAN, sygn. pr. dokt. 122). Wśród ogromnej literatury dotyczącej historii Warszawy należy wymienić kilka prac z zakresu historii społeczno-gospodarczej, na które szczególnie warto zwrócić uwagę: E. Koczorowska-Pielińska, Liczebność i specjalizacja rzemiosła $w$ Starej $i$ Nowej Warszawie $w$ latach 1417-1526, „Rocznik Warszawski” (dalej: RW) 11, 1972, s. 5-22; taż, Paśnicy i szewcy w Starej $i$ Nowej Warszawie w latach 1416-1526, RW 14, 1976, s. 83-113; taż, Przyjęcia do prawa miejskiego miasta Nowej Warszawy w latach 1477-1525, RW 9, 1969, s. 261295; taż, Struktura gospodarczo-społeczna Nowej Warszawy w XV wieku, PH, t. 49, 1958, z. 2, s. 296-310; taż, Warszawskie rzemiosto artystyczne $i$ budowlane $w X V w$., Warszawa 1959; T. Chudoba, Warszawski rynek zbożowy w XVI wieku, RW 6, 1967, s. 15-47; tenże, $Z$ zagadnień handlu wiślanego Warszawy w XVI wieku, PH, t. 50, 1959, z. 2, s. 297-321; M. Biskup, Handel wiślany w latach 1454-1466, RDSG 14, 1952, s. 165-202; S. Russocki, Uwagi o polityce targowej ksiażat mazowieckich $w$ XIV i XV w., PH, t. 51, 1960, z. 2, s. 275-284; A. Wawrzyńczyk, Rola Warszawy w handlu $z$ W. Ks. Litewskim i Rosja $w$ XVI w., „Kwartalnik Historyczny” 63, 1956, 2, s. 3-26; M. Biskup, Z problematyki handlu polsko-gdańskiego drugiej połowy XV wieku, PH, t. 45, 1954, z. 2-3, s. 390-407; M. Małowist, Podstawy gospodarcze przywrócenia jedności państwowej Pomorza Gdańskiego z Polska w XV w., PH, t. 45, 1954, z. 2-3, s. 141-187; A. Bartoszewicz, Handel sola na Mazowszu w XV i XVI wieku, „Rocznik Mazowiecki” 18, 2006, s. 47-62; M. Sałański, Rzemieślnicy, kupcy, kramarze. Przyczynek do rozwoju Warszawy i przedsiębiorczości jej mieszkańców od XIV w. do I połowy XVI w., w: Z dziejów Warszawy. Przedsiębiorczość, red. K. Wagner, Warszawa 2013, s. 9-25. P. Łozowski, Pieniadze bogaczy, czyli obce monety w Starej Warszawie pierwszej połowy XV stulecia, w: Moneta czasów kryzysu - moneta czasów pomyślności, red. B. Paszkiewicz, Nowa Sól 2015, s. 153-183. 
późnego średniowiecza, możemy dostrzec mechanizmy, przyczyny, przebieg i skutki rozwoju ekonomicznego miasta zaliczanego w literaturze do kategorii średnich ${ }^{17}$.

Celem niniejszego artykułu jest zaprezentowanie szczegółowej struktury gospodarczej warszawskiego rynku kredytowego w pierwszej połowie XV stulecia. Określenie dynamiki zapisów, wysokości obrotów, poziomu koncentracji kapitału, długości trwania umów, ich sezonowości, sposobów zabezpieczania oraz funkcjonowania systemu ratalnego, pozwoli zarysować szerokie tło gospodarcze życia miejskiego. Wyniki badań nad ruchem pożyczkowym stanowia jeden z podstawowych i najbardziej wyrazistych mierników stopnia rozwoju ekonomicznego badanego ośrodka. Oprócz poznania ogólnej kondycji gospodarki miasta niezwykle istotnym elementem jest zbadanie kierunków i poziomu aktywności mieszkańców civitatis Antiquae Varsoviae. Zadanie to ułatwia materiał zawarty $\mathrm{w}$ najstarszych $\mathrm{z}$ zachowanych księgach sądowych ${ }^{18}$, które przekazują informacje nie tylko o dużym kredycie patrycjuszowskim ${ }^{19}$, ale też i drobnym, zaciaganym przez najliczniej występujace pośród posiadaczy ius civile pospólstwo i w pewnej części nawet plebs. Chociaż kwestionariusz pytań badawczych został przygotowany tak, aby uzyskać i wykorzystać jak największą ilość informacji i danych oferowanych przez źródło, to trzeba mieć świadomość, iż w księgach sądowych chwytamy jedynie część obrotów, a rzeczywista ich skala jest trudna do ustalenia.

\section{Charakter miejskich rynków kredytowych}

Przeprowadzoną analizę osadzono na szerszym tle porównawczym obejmującym także rynki kredytowe tworzone przez szlachtę ${ }^{20}$, chłopów ${ }^{21}$,

${ }_{17}$ M. Bogucka, H. Samsonowicz, dz. cyt., s. 117.

${ }^{18}$ Ksiegi tawnicze miasta Starej Warszawy z XV w., t. 1: Księa nr 525 z lat 1427-1453, wyd. S. Ehrenkreutz, Warszawa 1916, Pomniki Prawa Warszawskiego Archiwum Głównego, t. 3 (dalej: KłMSW). Dane z lat 1447-1453 zostały także uzupełnione o pochodzące z tego okresu zapiski obecne w: Księga radziecka miasta Starej Warszawy, t. 1: (1447-1527), wyd. A. Wolff, Wrocław-Warszawa-Kraków 1963 (dalej: KRMSW). Z podstawy źródłowej niniejszego artykułu zostały wyłączone zapisy dotyczące rynku nieruchomości, któremu to tematowi zostanie poświęcona osobna praca.

19 Por. R. Czaja, Kredyt pieniężny..., s. 5-19, gdzie do staromiejskiej księgi ławniczej trafiał głównie kredyt patrycjuszowski o średniej wartości kilkudziesięciu grzywien.

${ }^{20}$ M. Urbański, dz. cyt., s. 627-651; M. Ungeheuer, dz. cyt.; A. Rutkowski, Warszawski rynek..., s. 69-81; Z. Morawski, dz. cyt.

${ }^{21}$ P. Guzowski, Chtopi i pieniadze... 
Żydów ${ }^{22}$, mieszczan w Sieradzu ${ }^{23}$, Warcie ${ }^{24}$ i ośrodkach południowego pobrzeża Bałtyku (Greifswald, Gdańsk, Elblag, Toruń, Rewel) ${ }^{25}$. Cecha wspólną w zasadzie wszystkich rynków była jednokrotna obecność ok. 2/3 uczestników ${ }^{26}$ oraz ich społeczna homogeniczność - w Starej Warszawie blisko $97 \%$ zidentyfikowanych dłużników pochodziło z warstwy mieszczańskiej, w przypadku wierzycieli było to ok. $80 \%{ }^{27}$. Podobny charakter dostrzeżono wśród uczestników szlacheckiego obrotu kredytowego ${ }^{28}$. Trzeba jeszcze $\mathrm{w}$ tym miejscu poczynić pewna uwage $\mathrm{w}$ stosunku do możliwości komparatystycznych z badanymi przez C. Kardasza rynkami miast hanzeatyckich. Znacząca różnica tkwi w formie rynku kredytowego, który w miastach strefy bałtyckiej oparty był głównie o system kupna/sprzedaży rent ${ }^{29}$, czyli sferę długoterminowej lokaty kapitału. Natomiast znacznie mniej zaawansowany gospodarczo rynek warszawski funkcjonował dzięki pożyczkom krótkoterminowym (rzadko dłuższym niż rok). Warto podkreślić, że udział zapisów rentowych sięgał zaledwie $4 \%$ transakcji. Zatem uczestnikom tych dwóch różnych rynków przyświecały nieco inne cele - renty z jednej strony zaspokajały potrzebę długoterminowej (czasem nawet kilkuletniej) lokaty kapitału, chęci zapewnienia sobie periodycznych dochodów przez określony typem renty $\operatorname{czas}^{30}$, zaś z drugiej - umożliwiały dłużnikowi zdobycie jednorazowo większej sumy pieniędzy przy stosunkowo niskim oprocentowaniu (między 6,66 a 10\% ${ }^{31}$ ). W przypadku rynku staromiejskiego

22 A. Rutkowski, Kredyt żydowski..., s. 267-284.

${ }^{23}$ U. Łydkowska-Sowina, dz. cyt., s. 119-135.

${ }^{24}$ A. Bartoszewicz, dz. cyt., s. 117-130.

${ }^{25}$ C. Kardasz, Rynek kredytu...; R. Czaja, Kredyt pieniężny...

${ }^{26}$ C. Kardasz, Rynek kredytu..., s. 93, 114, 123, 137, 149, 164, 176; J.L. van Zanden, J. Zuijderduij, T. de Moor, dz. cyt., s. 17; A. Bartoszewicz, dz. cyt., s. 123-124. W materiale warszawskim łącznie zanotowano 579 osób bioracych udział w obrocie pożyczkowym - 304 osoby po stronie wierzycieli i 275 wśród dłużników. W gronie pożyczkobiorców ponad 80\% wystapiło jednokrotnie, w przypadku pożyczkodawców było to $75 \%$, natomiast po obu stronach rynku działało 40 osób, czyli zaledwie $7 \%$ całości grupy.

27 Ustalono na podstawie grupy 181 dłużników i 201 wierzycieli. Z obliczeń wyłaczono grupę 94 osób niezidentyfikowanych stanowo pośród dłużników i 103 osób wśród wierzycieli.

28 M. Ungeheuer, dz. cyt., s. 239.

${ }^{29}$ C. Kardasz, Rynek kredytu..., s. 15, 31, 237.

${ }^{30}$ Większość stanowiły renty nowe o charakterze wykupnym, a więc dłużnik mógł zakończyć umowę w korzystnym dlań czasie. Warto również wspomnieć m.in. o typach rent wieczystych i dożywotnich, zob. szerzej C. Kardasz, Rynek kredytu..., s. 33-38, 82 n.; B. Lesiński, dz. cyt., s. 135-155.

${ }^{31}$ C. Kardasz, Rynek kredytu...., s. 238. 
opartego na niedużym kredycie krótkoterminowym trudno jest mówić o bezpiecznej lokacie, należałoby raczej przychylić się do twierdzenia o sporadycznym uczestnictwie w obrocie mającym na celu wykorzystanie nadwyżek pieniądza zdobytego $\mathrm{w}$ handlu oraz zadośćuczynienia wzrastającemu popytowi na kredyt konsumpcyjny, ewentualnie inwestycyjny (zakup nieruchomości/handel) ${ }^{32}$. Wniosek z powyższego jest następujący: w źródłach miast strefy bałtyckiej nie mamy informacji o niewielkich pożyczkach krótkoterminowych ${ }^{33}$, które przecież były niezbędnym elementem drobnego życia kredytowego (szczególnie pośród mieszkańców nieposiadajacych prawa miejskiego i dóbr nieruchomych), więc $\mathrm{w}$ toku dalszej analizy należy mieć na uwadze, iż porównujemy rynki o odmiennej strukturze i zasobie danych.

Kwestia systemu monetarnego Starej Warszawy i jego zróżnicowania została już szeroko omówiona $\mathrm{w}$ innym miejscu ${ }^{34}$. W tym momencie należy wspomnieć, iż gospodarka warszawska opierała się głównie ${ }^{35}$ o rachowane w systemie kopowym (sexagena) półgrosze koronne Władysława Jagiełły (mediorum grossorum). Oprócz monet polskich notujemy też szerokie grosze praskie (sexagenas latorum grossorum Pragensium) występujące wśród 8,9\% spraw $^{36}$, szelagi pruskie ${ }^{37}$ (solidorum marcas Pruthenicales) majace udział w 1,9\% spraw i złote floreny węgierskie $^{38}$ (floreni Ungaricales) notowane pośród 1,5\% zapisów. Na potrzeby niniejszego studium będziemy się posługiwać groszową jednostką obliczeniową w stosunku 1 grosz $=2$ półgrosze koronne ${ }^{39}$.

${ }^{32} \mathrm{~W}$ literaturze obecne jest także twierdzenie o zwiększeniu aktywności kupieckiej na rynku kredytowym w momencie kryzysu handlowego (C. Kardasz, Rynek kredytu..., s. 89 i n.). Niemniej jednak na podstawie zachowanych źródeł z reguły trudno jest jednoznacznie wskazać przyczynę zwiększonych inwestycji, czy był to kryzys, czy też pomyślna koniunktura handlowa. W przypadku Starej Warszawy raczej należałoby się upatrywać pomyślnej koniunktury handlowej, więcej zob. przyp. 47.

${ }^{33}$ C. Kardasz, Rynek kredytu..., s. 50-52. Warto zwrócić uwagę, iż nie wszystkie miasta wymagały nawet wpisania transakcji rentowej dotyczącego przecież nieruchomości, więc trudno spodziewać się księgowania setek drobniejszych, krótkoterminowych umów.

${ }_{34}$ P. Łozowski, Pieniadze bogaczy...

${ }_{35} \mathrm{~W} 87 \%$ zapisów o charakterze ekonomicznym.

${ }^{36} 1$ grosz praski = 1,5 grosza obliczeniowego; Z. Żabiński, Systemy pieniężne na ziemiach polskich, Wrocław 1981, Tabela 17 (s. 51), 54.

${ }^{37} 1$ grzywna pruska $=22,5$ groszy obliczeniowych; przeliczone na podstawie: tamże, Tabela 32 (s. 69); por. S. Kubiak, Monety i stosunki monetarne w Prusach Królewskich $w 2$ połowie XV wieku, Wrocław 1986, s. 127.

381 floren węgierski=36 groszy obliczeniowych; wynik stanowi średniąarytmetyczna wartości dukata w Polsce w latach 1421-1460; Z. Żabiński, dz. cyt., Tabela 17 (s. 51).

39 Tamże, Tabela 19 (s. 56). 
Tabela 1. Obroty rynków kredytowych wybranych miast w późnym średniowieczu

\begin{tabular}{l|c|c|c|c}
\hline \multicolumn{1}{c|}{ Ośrodek } & Lata & $\begin{array}{c}\text { Wartość zapisów } \\
\text { (w groszach) }\end{array}$ & $\begin{array}{c}\text { Liczba } \\
\text { zapisów }\end{array}$ & $\begin{array}{c}\text { Częstotliwość } \\
\text { roczna } \\
\text { (waokrągleniu) }\end{array}$ \\
\hline Stara Warszawa & $1427-1453$ & 451617 & 464 & 18 \\
\hline Sieradz & $1432-1457$ & 12768 & 133 & 5 \\
\hline Warta & $1484-1512$ & 14000 & 57 & 26 \\
\hline Greifswald & $1425-1442$ & $249576 *$ & 452 & 115 \\
\hline Główne Miasto Gdańsk & $1426-1441$ & $2056500^{*}$ & 1729 & 104 \\
\hline Młode Miasto Gdańsk & $1400-1455$ & $41670 *$ & 496 & 11 \\
\hline Stare Miasto Elblą** & $1400-1417$ & $649192 *$ & 325 & 14 \\
\hline Stare Miasto Toruń & $1425-1453$ & $740317 *$ & 354 & 12 \\
\hline Nowe Miasto Toruń & $1425-1450$ & $329580^{*}$ & 347 & 29 \\
\hline Rewel & $1425-1453$ & $917494^{*}$ & 14 \\
\hline
\end{tabular}

Źródło: obliczenia własne na podstawie KŁMSW, KRMSW; U. Łydkowska-Sowina, dz. cyt., s. 26 i n.; A. Bartoszewicz, dz. cyt., s. 119; C. Kardasz, Rynek kredytu..., Aneks: s. 326-327, 331-332, 336, 348349, 352-353, 360 .

* Wartości przeliczone z grzywien pruskich na grosze obliczeniowe wg stosunku 1 grzywna $=22,5$ grosza. Kurs ustalony na podstawie relacji grzywna pruska - grosz praski (Z. Żabiński, dz. cyt., Tabela 32, s. 69). Natomiast do przeliczeń grzywien wendyjskich stosowanych w Greifswaldzie i reńskich w Rewlu, posłużono się relacją w zawartości srebra między tymi jednostkami a grzywna pruską przedstawionej w bazach danych opracowanych przez London School of Economics http://www.lse.ac.uk/economicHistory/Research/Late\%20Medieval\%20Financial\%20Market/datasheets/datasheetindex.aspx (dostęp: 23 VI 2015), gdzie po uśrednieniu wartości pochodzących z lat 1300-1500 przyjęto stosunek grzywny pruskiej do wendyjskiej na 1:4 i pruskiej do reńskiej na 1:1,2.

** Pominięto rynek Nowego Miasta Elbląga, gdyż dane są dostępne jedynie dla lat 1340-1381.

Historycy są zgodni, iż obroty i dynamika rynku kredytowego stanowia podstawowy wskaźnik kondycji ekonomicznej badanego ośrodka/ region $\mathrm{u}^{40}$. Na podstawie zestawienia transakcji kredytowych zapisanych w księgach miejskich (tabela 1) możemy zaobserwować, jak znaczące różnice w wartości obrotu i jego dynamiki zachodziły pomiędzy rynkami miast małych (Sieradz, Warta), średnich (Warszawa) i dużych (np. Gdańsk). Należy jednak mieć na uwadze fakt wspominanego wyżej zróżnicowania typów rynków oraz znacznej (lecz trudnej do określenia) liczby zapisów niezarejestrowanych. Warszawski ruch kredytowy drugiej ćwierci XV w. stanowił w tym samym czasie zaledwie $22 \%$ wartości obrotów Głównego Miasta Gdańska, 49\% Rewla i 61\% Starego Miasta Torunia. Co interesujące, suma obrotów w Starej Warszawie blisko dwukrotnie przewyższała ruch pieniężny w Greifswaldzie i nieco

${ }^{40}$ R. Czaja, Rynek kupna..., s. 29; M. Urbański, dz. cyt., s. 627; C. Kardasz, Rynek kredytu..., s. 197-201. 
się wyrównywała dopiero porównaniu z Nowym Miastem Toruniem. Natomiast największe rozbieżności dostrzegamy w przypadku Sieradza i Warty, których ruch pożyczkowy w stosunku do Starego Torunia opiewał na około $2 \%$, zaś Gdańska zaledwie 0,7\%! Dysproporcja w porównaniu ze Stara Warszawą była ogromna (ponad 32-krotna), stanowiąc jednocześnie $3 \%$ całości warszawskiego rynku kredytowego. W momencie, gdy przyjmiemy klasyfikację miast z około 1500 r. przedstawiona w pracy Marii Boguckiej i Henryka Samsonowicza ${ }^{41}$, różnice pomiędzy ośrodkiem pierwszej (Gdańsk, Elblag, Toruń), drugiej (Stara Warszawa) i trzeciej (Warta i Sieradz ${ }^{42}$ ) kategorii stają się jeszcze wyraźniejsze. Mimo iż wskazana klasyfikacja jest o ponad pół wieku późniejsza od prezentowanych wyników, a sytuacja ekonomiczna wszystkich ośrodków ulegała zmianie w drugiej połowie XV stulecia, zaprezentowane proporcje nie tylko jasno pokazują różnice w poziomie rozwoju gospodarczego najpowszechniej w Królestwie występujących miast średnich i małych, ale również kilku ośrodków najzamożniejszych. Jeśli nawet pominiemy wyjątkowy przykład Gdańska i za bardziej miarodajny dla ogółu miast pierwszej kategorii uznamy wynik Starego Torunia, to stosunek między ośrodkami trzech kategorii będzie się przedstawiał jak 1:1,6 (Toruń-Warszawa), 1:58 (Toruń-Sieradz) i 1:32-35 (WarszawaWarta/Sieradz). Warto jeszcze zwrócić uwagę na częstotliwość zapisów, która zarówno w civitates pierwszej, jak i drugiej kategorii oscylowała w granicach kilkunastu umów rocznie.

Największe jednak dysproporcje w ilości i całkowitej wartości transakcji są widoczne pomiędzy mieszczańskim a ziemskim rynkiem kredytowym. Wielkość obrotów pożyczkowych w ziemi sanockiej w latach 1423-1506 (1867 spraw, ok. 22 rocznie) wyraża się zawrotną suma ok. 14227665 gr $^{43}$, zaś w ziemi przemyskiej suma zapisów dłużnych w latach 1436-1468 (2019 spraw, ponad 63 rocznie!) osiagnęła prawie 3-krotnie mniejszą wartość, wynosząc ok. $4939023 \mathrm{gr}^{44}$. Już nawet proste porównanie bliskich sobie chronologicznie rynków kredytowych warszawskiego i przemyskiego pokazuje znaczne różnice w ilości $(1: 4,5)$ i wartości zapisów (1:12). Ziemski ruch pożyczkowy leżał przede wszystkim w obszarze zainteresowania rozmaitych grup szlachty $(70-80 \%$

${ }^{41}$ M. Bogucka, H. Samsonowicz, dz. cyt., s. 115-118.

${ }^{42}$ M. Bogucka i H. Samsonowicz w swoim zestawieniu zarówno Sieradz, jak i Warszawę w roku 1500 uznali za miasta II kategorii (tamże, s. 115, 117), lecz już w 1520 r. rejestr pogłównego zalicza Sieradz do miast III kategorii; U. Łydkowska-Sowina, dz. cyt., przyp. 3.

${ }_{43}$ M. Urbański, dz. cyt., s. 631.

${ }^{44}$ M. Ungeheuer, dz. cyt., s. 111. 
uczestników), w wyniku czego udział mieszczan kształtował się z reguły na poziomie $7-8 \%{ }^{45}$. Jeśli weźmie się dodatkowo pod uwagę nieliczna grupę Żydów $\left(1 \%{ }^{46}\right)$, możemy mówić o hermetycznym i samowystarczalnym ziemskim rynku kredytowym opierającym się głównie na kapitale będącym w posiadaniu szlachty.

Z kolei obserwacja chłopskiego rynku kredytowego w latach 1408$1450^{47}$ wskazuje, że uczestnictwo w obrocie pieniądzem mieszkańców kilku zbadanych wsi położonych na terenie Małopolski i Rusi Czerwonej odbywało się raczej sporadycznie (419 zapisów na przestrzeni 42 lat, średnio 10 transakcji rocznie). Był to też rynek pożyczek drobnych, o czym świadczy chociażby całkowita wartość wpisów wynosząca 123191 gr, czyli 27\% warszawskich obrotów kredytowych - co warto podkreślić - zanotowanych w czasie krótszym o prawie dwie dekady. W świetle powyższych danych dotyczących wszystkich rodzajów rynków kredytowych, należy rynek pożyczek chłopskich uznać za stosunkowo ubogi i umiarkowanie dynamiczny ${ }^{48}$.

\section{Dynamika warszawskiego rynku kredytowego}

Pierwszym etapem analizy ukazującej poziom gospodarczy staromiejskiego rynku kredytowego jest zagadnienie częstotliwości zapisów. Z najstarszej z zachowanych ksiag ławniczych Starej Warszawy udało się wyodrębnić w sumie 464 umowy pożyczkowe (wykres 1).

Każdego roku do ksiąg trafiało średnio ok. 18 umów kredytowych, przy czym rozpiętość wahała się od 6 do 30 zapisów rocznie. Doskonale widoczna jest także tendencja wzrostowa, za której początek można uznać drugą połowę lat 30. XV w. Dane z wykresu dobrze koresponduja z uwagami Henryka Samsonowicza o pomyślnej koniunkturze gospodarczej i dynamicznym rozwoju Starej Warszawy w pierwszej połowie XV stulecia ${ }^{49}$. Liczba 11 zapisów pod rokiem 1427 pokazuje, iż stosowny

${ }^{45}$ Tamże, s. 239; M. Urbański, dz. cyt., s. 646; H. Samsonowicz, Local..., s. 55.

${ }^{46}$ Dane wyłącznie dla ziemi przemyskiej: M. Ungeheuer, dz. cyt., s. 111.

${ }^{47}$ Początkowa data zestawienia została wyznaczona na podstawie pochodzacej z Krościenka Wyżnego najstarszej z analizowanych przez autora ksiag wiejskich, zob. P. Guzowski, Chtopi i pieniadze..., s. 46 (tabela 1). Cenzurę końcową przyjęto za autorem (tamże, s. 65, tabela 6).

${ }^{48}$ Zob. podobne rozważania w: tamże, s. 66-68.

${ }^{49}$ H. Samsonowicz, Warszawa w handlu średniowiecznym, w: Warszawa średniowieczna, red. A. Gieysztor, z. 2, Warszawa 1972, s. 31. Około 63\% spraw handlowych wpisanych do analizowanej księgi ławniczej dotyczy transakcji zawartych po roku 1440. Zob. szerzej na ten temat: H. Samsonowicz, tamże, s. 9-31; tenże, Warszawa 
Wykres 1. Liczba zapisów kredytowych w Starej Warszawie w latach 1427-1453

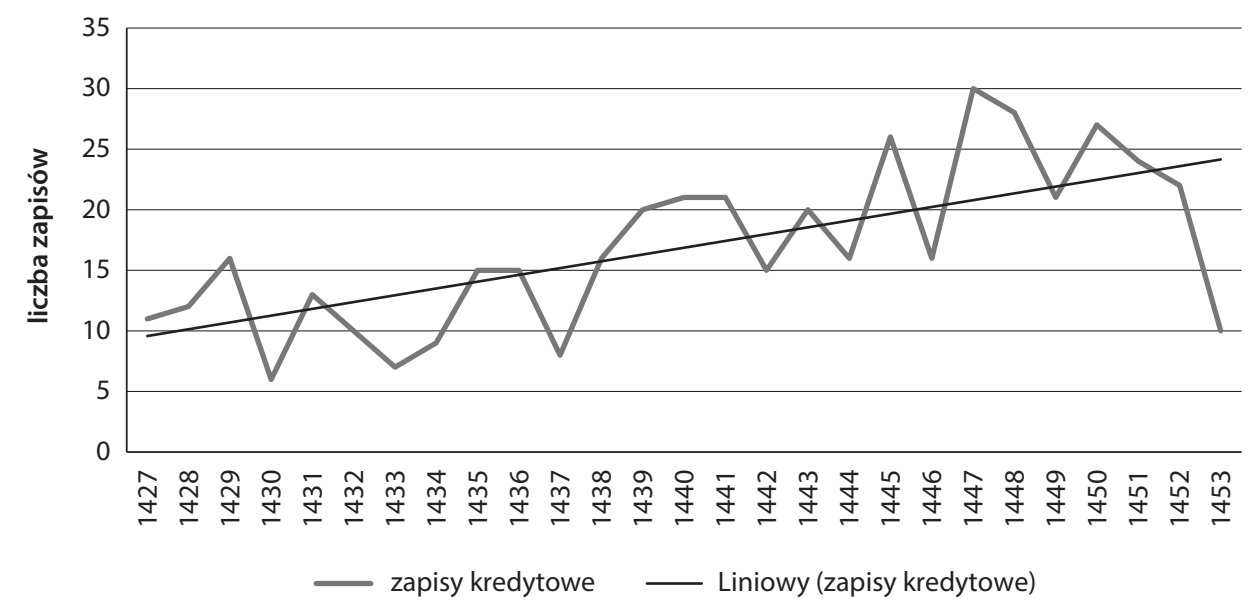

Źródło: KŁMSW, KRMSW

formularz kancelaryjny był już w Starej Warszawie znany i powszechnie stosowany przynajmniej w latach 20. XV stulecia. Potwierdza to przypuszczenia Stefana Ehrenkreutza, że wydana przezeń księga ławnicza nie jest najstarszą $\mathrm{z}$ istniejących, lecz jedynie z zachowanych, a wcześniej powinna funkcjonować przynajmniej jedna księga ją poprzedzająca ${ }^{50}$. Należy mieć również na uwadze fakt, iż spadek liczby zapisów począwszy od roku 1451 związany jest z powstaniem kolejnej księgi ławniczej obejmującej lata $1453-1472^{51}$. Jak pokazuje wykres 1, najlepsza koniunktura gospodarcza przypada na lata 40 . XV w., kiedy to liczba zapisów oscyluje w granicach 20-30 rocznie, co $\mathrm{w}$ porównaniu do poziomu z lat wcześniejszych oznacza przynajmniej dwukrotny wzrost.

\section{Wartość umów kredytowych}

Oprócz rocznej liczby zapisów, dobrą ilustracją rozwoju gospodarczego Starej Warszawy jest tendencja rosnącej wartości kontraktów kredytowych w poszczególnych latach (zob. wykres 2).

jako węzet komunikacyjny w dawnej Polsce, „Kronika Warszawy” 9, 1978, nr 3, s. 5-12; tenże, Przemiany osi drożnych w Polsce późnego średniowiecza, PH, t. 64, 1973, z. 4, s. $697-716$.

50 KŁMSW, s. VIII.

${ }^{51}$ Archiwum Główne Akt Dawnych, Stara Warszawa 527. 
Dynamiczny rozwój stosunków kredytowych rozpoczyna się już $\mathrm{w}$ latach 30., a zwłaszcza w ich drugiej połowie, kiedy to wartość rocznych zapisów wzrasta trzykrotnie z około 5000 do powyżej 15000 gr (1432). Następny gwałtowny skok ma miejsce w 1436 r., gdy wartość transakcji sięga 40000 gr rocznie, a więc niemalże ośmiokrotnie więcej niż w trzeciej dekadzie tego stulecia! Od tego momentu, aż do połowy XV w. średnio co 2-4 lata ogólna suma umów kredytowych przekracza 30000 gr. Te nagłe skoki obrazuja rosnaca aktywność gospodarczą głównie staromiejskich patrycjuszy, którzy dysponując coraz większym kapitałem, systematycznie wprowadzali go na rynek. Kupieckie majątki rosły m.in. wraz z rozwojem handlu wiślanego, poprzez który warszawscy mercatores nawiązywali żywe kontakty z Toruniem i Gdańskiem ${ }^{52}$. Dostrzegalne 2-4-letnie odstępy pomiędzy momentem ponownego pojawienia się dużego kapitału na rynku moga, z jednej strony, obrazować, po jakim czasie patrycjuszowi zwracała się jego kupiecka inwestycja i był on w stanie spłacić zaciagnięty dług bądź też udzielić kolejnego kredytu, z drugiej zaś - świadczyć o stałym zapotrzebowaniu na dużą gotówkę niezbędną w prowadzeniu handlu w skali ponadregionalnej. Podobna prawidłowość obserwujemy także w miastach strefy bałtyckiej, gdzie rozkład wartości zapisów notuje cykliczne, występujące naprzemiennie z roku na rok spadki i wzrosty ${ }^{53}$. Co równie interesujące, w latach 1425-1450 dostrzegamy zbliżony do warszawskiego poziom rocznej wartości zapisów kredytowych (20 000-40 000 gr) również w Starym Mieście Toruniu i Rewlu ${ }^{54}$.

${ }^{52}$ H. Samsonowicz, Warszawa w handlu..., passim; KŁMSW, nr 264, 291, 442, $553,613,924,1065,1285$. W dotychczasowej literaturze przyjmowano, iż w kontaktach z Warszawą w XV w. pośród kupców pruskich dominowały osoby pochodzące z Torunia (H. Samsonowicz, tamże, s. 18; W. Sieradzan, Sasiedztwo mazowiecko-krzyżackie w okresie przemian politycznych $w$ Europie Środkowo-Wschodniej w latach 1411-1466, Toruń 1999, s. 189). Niemniej jednak już nawet na podstawie dokonanego zestawienia widać, iż w relacjach gospodarczych Starej Warszawy z państwem krzyżackim rolę zdecydowanie bardziej znaczaca odgrywali mercatores de Danczko. Potwierdzenie tej tezy może kryć się w warszawskiej księdze ławniczej, gdzie ogółem zarejestrowano 39 spraw, w których występowały osoby pochodzące z Gdańska i 17 z udziałem mieszkańców Torunia; KŁMSW, nr 46, 256, 264, 290, 291, 410, 415, 442, 447, 471, 559, 577, $578,654,661,769,827,862,876,924,1064,1065,1088,1116,1129,1148,1149,1189$, 1198, 1221, 1237, 1250, 1251, 1285, 1286, 1289, 1355, 1363, 1425 (Gdańsk); tamże, nr 32, 45, 235, 288, 297, 340, 343, 553, 591, 613, 907, 1184, 1193, 1212, 1357, 1358, 1468 (Toruń). Jednakże konstrukcja pełnego obrazu tegoż zagadnienia będzie możliwa dopiero po przeprowadzeniu szerokiej kwerendy w źródłach pruskich.

${ }_{53}$ C. Kardasz, Rynek kredytu..., s. 299 (Greifswald), 303 (Gdańsk), 305 (Elblag), 310 (Stary Toruń), 313 (Nowy Toruń), 314 (Rewel).

${ }^{54}$ Tamże, s. 310, 314. 
Wykres 2. Wartość zapisów kredytowych w Starej Warszawie w latach 1427-1453

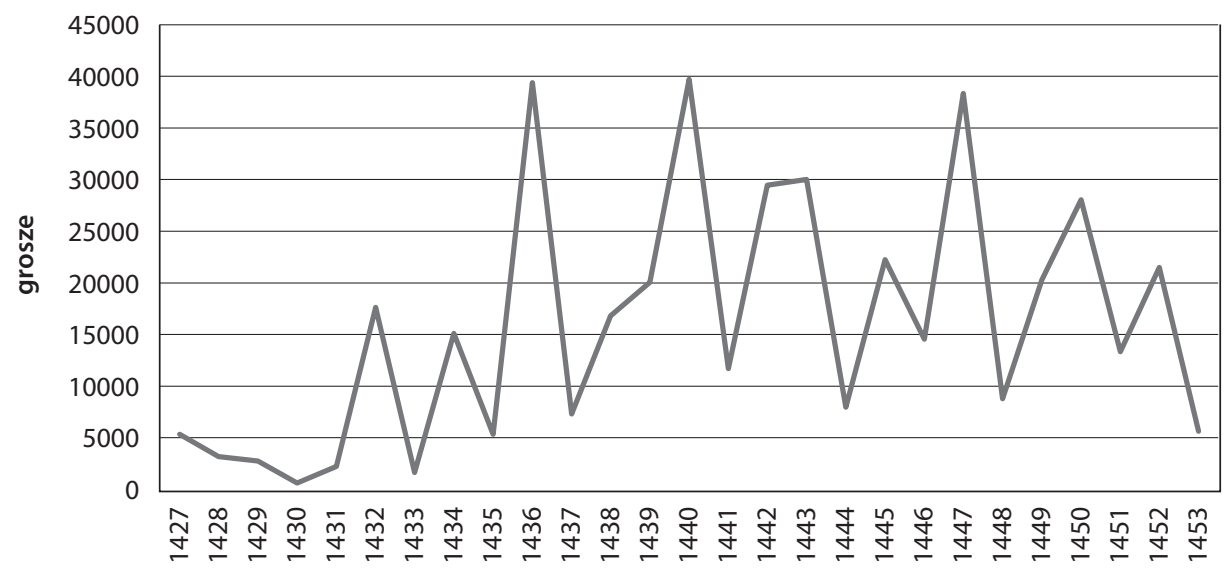

wartość

Źródło: KŁMSW, KRMSW

Wykres 3. Wartość zapisów kredytowych w Starej Warszawie w latach 1427-1453średnia i mediana

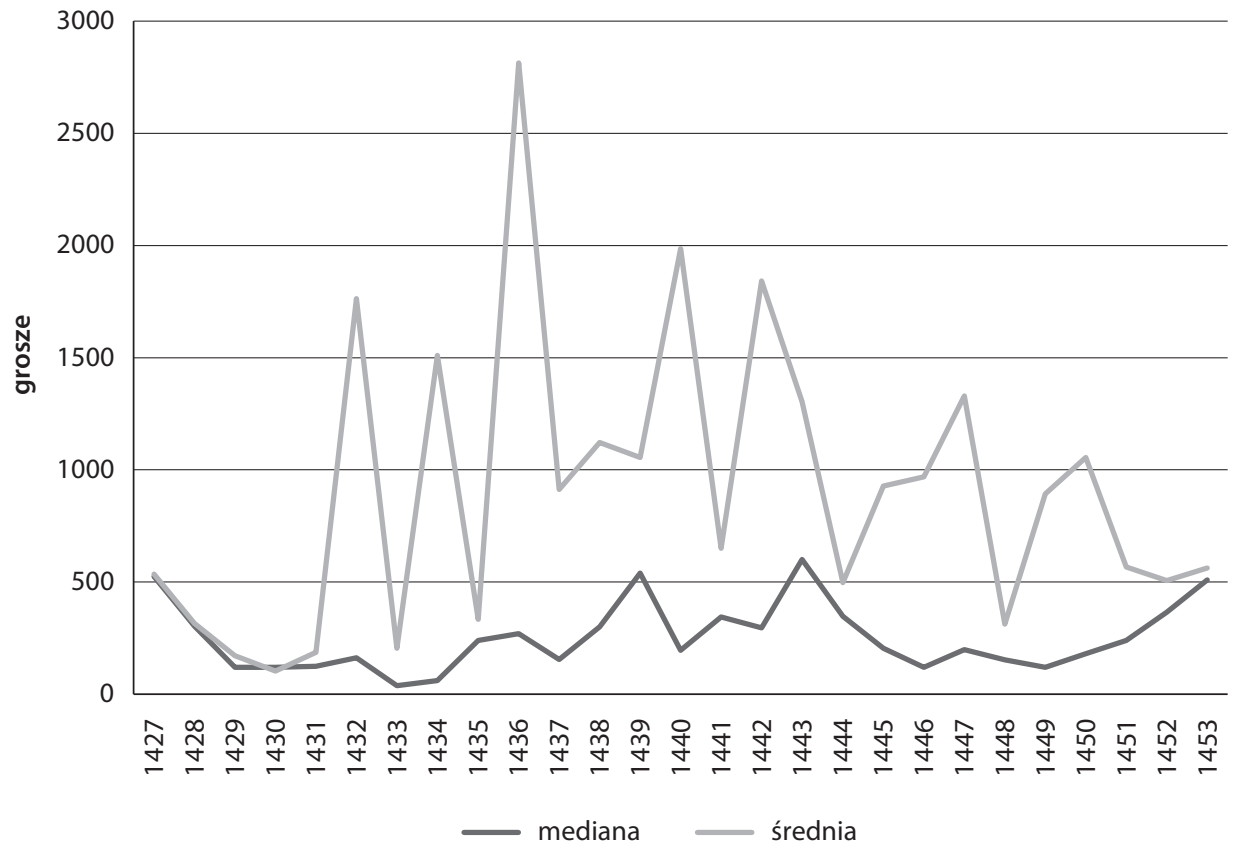

Źródło: KŁMSW, KRMSW 
Dokładne wyjaśnienie zasygnalizowanego zjawiska wymaga jednak przeprowadzenia dalszych pogłębionych studiów nad systemem pracy kupców, w szczególności zaś częstotliwości i czasu trwania podejmowanych przezeń inwestycji.

$\mathrm{Na}$ warszawskim rynku obok dużych pożyczek inwestycyjnych występował też kredyt drobny, zwany konsumpcyjnym, zaciagany głównie przez przedstawicieli pospólstwa. W określeniu jego przybliżonych rozmiarów niezbędne jest wykorzystanie podstawowych miar tendencji centralnej, czyli mediany i średniej arytmetycznej (wykres 3). Zastosowanie mediany pozwoliło wydzielić dwie sfery rynku kredytowego. Pierwsza, zamykajaca się w przedziale do 10 kop (600 gr), obejmowała rynek drobnych pożyczek konsumpcyjnych oraz niewielkich inwestycyjnych, natomiast powyżej tej granicy można umiejscowić kredyt duży, związany głównie z wielostronną aktywnościa gospodarczą patrycjatu. Występowanie dużych rozbieżności między średnią a mediana - oznaczających istnienie wartości skrajnych w szeregu liczbowym świadczy o fakcie zawarcia w danym roku kilku umów kredytowych znacznie odbiegających swoją wartościa od pozostałych ${ }^{55}$. Takie spojrzenie umożliwia jeszcze dokładniejsze wykrycie momentów szczególnej aktywności patrycjatu w ruchu pożyczkowym. Z wykresu wynika, iż miała ona miejsce w latach 1432, 1434, 1436, 1438, 1440, 1442, 1445-1447 i 1449-1450, co pozwala wskazać na istnienie dwuletniego cyklu koniunkturalnego dostrzegalnego w ekonomicznej działalności warstw najbogatszych. Wielokrotnie odnotowujemy obecność w tych latach postaci takich, jak m.in. Mikołaj Nerka ${ }^{56}$, Andrzej Edlinger ${ }^{57}$, Maciej Małodobry ${ }^{58}$, Mikołaj Bartkowicz ${ }^{59}$, Marcin Benesz ${ }^{60}$, Andrzej Pielgrzym $^{61}$, Stanisław Pieniążek ${ }^{62}$ czy Jan Hafciarz ${ }^{63}$. Tendencję

${ }^{55}$ Dobrym tego przykładem sa dwie umowy kredytowe z 1436 r.: pierwsza zawarta pomiędzy Markiem Komorowskim a Mikołajem Nerką i Andrzejem Kazubem, opiewająca na 80 kop szerokich groszy praskich (KÆMSW, nr 331), oraz druga, w której Andrzej kupiec poświadcza Hincze Glaserowi za Stanisława z Wilna na kwotę 396 grzywien minus 5 groszy, czyli 19003 gr (nr 358). Warto też wspomnieć o pożyczce udzielonej w roku 1440 przez Kuncze Guldemuta z Norymbergi Hermanowi Jelenowiczowi mieszczaninowi warszawskiemu na sumę 164,5 grzywien szerokich groszy praskich (nr 596).

\footnotetext{
${ }^{56}$ KŁMSW, nr 326, 376, 469, 549, 569, 587, 692, 718, 852, 857, 881, 882.

${ }_{57}$ Tamże, nr 679, 1063, 1198, 1308.

58 Tamże, nr 488, 1231.

59 Tamże, nr 703, 882, 911, 957, 1036, 1298.

60 Tamże, nr 1006, 1020, 1185.

61 Tamże, nr 449, 555, 566, 580, 838, 1031, 1250.

62 Tamże, nr 437, 909, 1062, 1158.

63 Tamże, nr 576, 1188, 1265, 1291, 1319.
} 
rozwojową wykazuje też rynek pożyczek drobniejszych, o czym świadczy rosnąca wartość mediany - szczególnie w latach 1435-1444.

O postępującym rozwoju rynku kredytowego świadczy z jednej strony zwiększająca się wartość samych kredytów, z drugiej zaś ich wzrastająca liczba. Roczne zestawienie liczby pożyczek w dwóch sferach rynku (do i powyżej 10 kop groszy) przedstawia wykres 4.

Wykres 4. Pożyczki w grupach do i powyżej 10 kop groszy w Starej Warszawie w latach 1427-1453

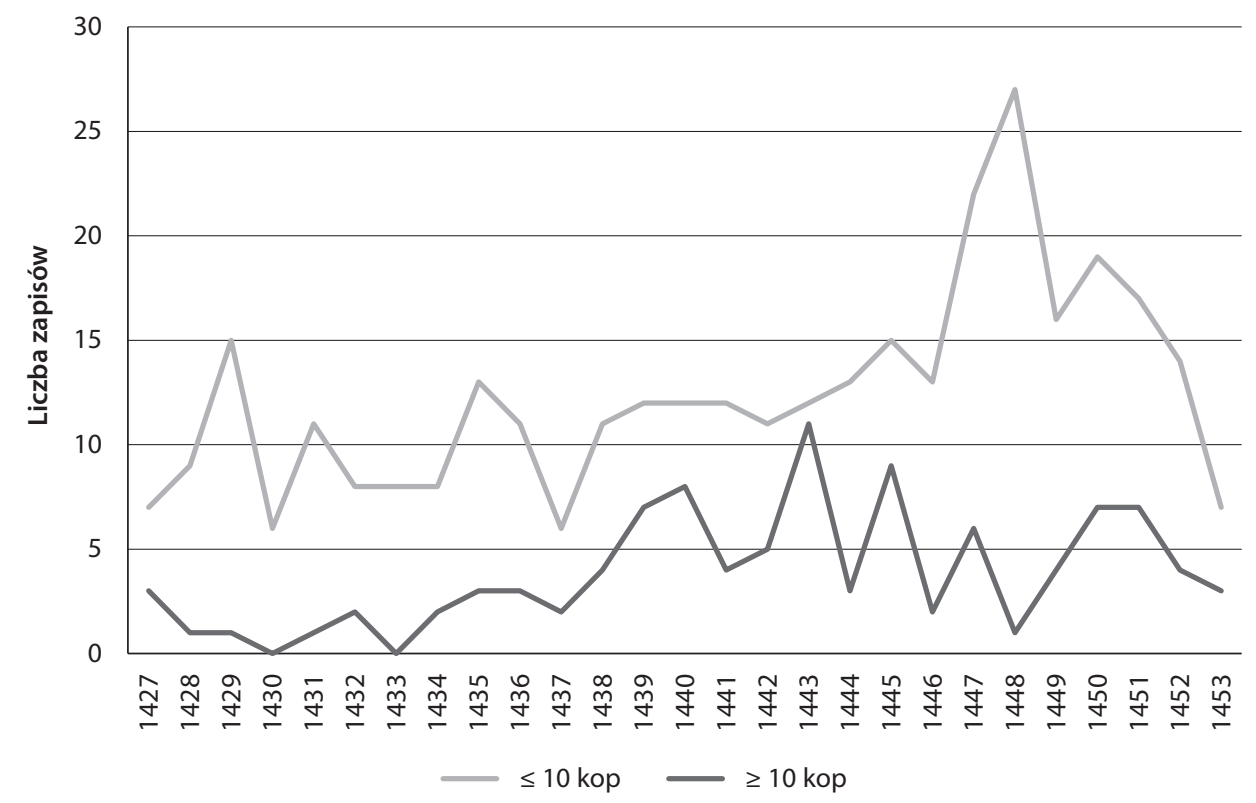

Źródło: KŁMSW, KRMSW

Obserwując grupę umów kredytowych obejmująca pożyczki powyżej 10 kop groszy, ponownie jesteśmy w stanie dostrzec (przypadający na lata 30.) moment zwiększonej aktywności gospodarczej warszawskich patrycjuszy. Okres korzystnej koniunktury, kiedy to liczba dużych pożyczek przekracza pięć rocznie ${ }^{64}$, rozpoczyna się od końca lat 30. i trwa przez resztę badanego okresu. Prosperity lat 40. także znalazły swoje odbicie na rynku pożyczek drobniejszych, których to liczba

${ }^{64} \mathrm{Na}$ podstawie tej wartości możemy dostrzec, iż warszawski patrycjat tworzyła stosunkowo niewielka grupa kupców opierająca swoją roczną działalność o zaledwie kilka transakcji. Szerzej na ten temat zob. P. Łozowski, Aktywność gospodarcza kupców i rzemieślników w Starej Warszawie pierwszej połowy XV stulecia, „Almanach Warszawy" 8, 2015, s. 23-46. 
gwałtownie rośnie w latach $1447-1452$ przekraczając 15 rocznie, sięgając nawet 27 (1448). Średnie roczne zapisów w obu badanych sferach rynku wyniosły kolejno 12 dla grupy „niższej” (do 10 kop gr) i prawie $4 \mathrm{w}$ grupie „wyższej” (powyżej 10 kop gr). Rocznie, zapisy należące do grupy drugiej stanowiły od $0(1430,1433)$ do maksymalnie $48 \%$ (1443) wszystkich umów kredytowych ('średnio 22\%). Największe dysproporcje sa jednak widoczne w ogólnej wartości zapisów wynoszącej 64536 gr (grupa I) i $387081 \mathrm{gr}$ (grupa II), a także w różnicach średniej rocznej wartości zapisu wynoszącej 190 gr (grupa I) i 3366 gr (grupa II). Spraw należących do grupy pierwszej było ponad trzykrotnie więcej niż w grupie drugiej, niemniej jednak proporcje w ich ogólnej (1:6) oraz średniej (1:18) wartości wyraźnie pokazują różnice pomiędzy dwiema sferami warszawskiego rynku kredytowego. Możemy również zauważyć, że aktywność elit kupieckich w obrocie pożyczkowym, pomimo wysokiego poziomu gospodarczego, charakteryzowała się niską dynamiką.

Niezwykle istotnym elementem w badaniu gospodarki jest określenie poziomu koncentracji ruchu pieniężnego w ramach określonych grup zamożności. Dane zawarte w tabeli 2 potwierdzają zjawisko koncentracji obrotów kredytowych (47\% wartości) w rękach stosunkowo niewielkiej grupy osób (4,5\% spraw). Podobna prawidłowość dostrzegamy również na innych zarówno miejskich ${ }^{65}$ jak i ziemskich ${ }^{66}$ rynkach kredytowych, ale poziom koncentracji jest zależny głównie od liczebności warstwy kupieckiej w danym ośrodku/regionie. W warszawskim ruchu pożyczkowym liczebnie dominują niewielkie pożyczki do 10 kop groszy (76\%), lecz ich wartość stanowi margines globalnych obrotów (14\%). W Starej Warszawie grupa najbogatszych patrycjuszy była jednak stosunkowo nieliczna i nie zdołała jednoznacznie zdominować większości rynku, jak to miało miejsce np. w Greifswaldzie (75\% umów powyżej 100 grzywien), Głównym Mieście Gdańsku (60\%), Starym Toruniu (78\%), Rewlu $(67 \%)^{67}$. Widać natomiast większy niż w wymienionych ośrodkach udział pożyczek średnich (10-99 kop), co świadczy o dużej (i rosnącej) aktywności pospólstwa.

Pomimo dominacji dużego kredytu kupieckiego w globalnym ruchu kredytowym civitatis Antiquae Varsoviae, największym zainteresowaniem cieszyły się jednak pożyczki mniejsze (wykres 5). W całym badanym okresie mediana przeciętnej umowy kredytowej wynosiła 200 gr (ponad 3 kopy), zaś średnia 976 (16 kop). Jednakże zdecydowana

\footnotetext{
${ }_{65}$ C. Kardasz, Rynek kredytu..., s. 327, 331, 349, 361.

${ }^{66}$ M. Urbański, dz. cyt., s. 634.

${ }^{67}$ C. Kardasz, Rynek kredytu..., s. 238.
} 
Tabela 2. Struktura wartości obrotów rynku kredytowego w Starej Warszawie w latach 1427-1453

\begin{tabular}{l|c|c|c|c}
\hline \multicolumn{1}{c|}{ Wartość (w kopach) } & $\mathbf{1 0}$ & $\mathbf{1 0 - 9 9}$ & $\mathbf{2 1 0 0}$ & Ogólem \\
\hline Liczba transakcji & 352 & 91 & 21 & 464 \\
\hline Wartość transakcji (w groszach) & 64536 & 174582 & 212499 & 451617 \\
\hline \% wartości & 14,3 & 38,7 & 47 & 100 \\
\hline \% liczby & 76 & 19,5 & 4,5 & 100 \\
\hline
\end{tabular}

Źródło: KŁMSW, KRMSW

Wykres 5. Struktura pożyczek należących do grupy I w Starej Warszawie w latach 1427-1453

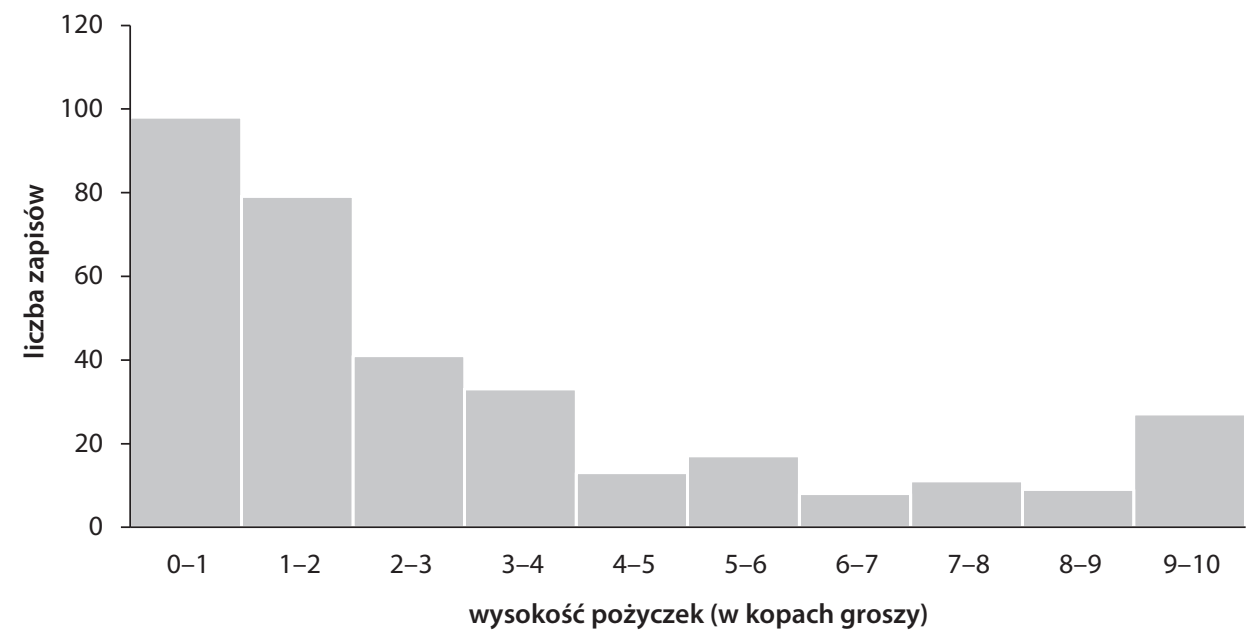

Źródło: KÆMSW, KRMSW

większość zapisów (76\%) nie przekraczała $10 \mathrm{kop}$, a połowa całego rynku mieściła się w grupie kredytów do 3 kop $(180 \mathrm{gr})^{68}$. Podobną strukturę obserwujemy na XV-wiecznym ziemskim i żydowskim rynku kredytowym powiatu warszawskiego, gdzie umowy kredytowe nieprzekraczające 10 kop stanowiły kolejno $77 \%{ }^{69}$ i $88 \%{ }^{70}$. W przypadku ziemi przemyskiej pożyczki o wartości do 20 grzywien (16 kop) stanowiły

${ }^{68}$ Dokładne proporcje pożyczek grupy I względem całości umów kredytowych wynoszą kolejno: do 1 kopy 22\%, do 2 kop $40 \%$, do 3 kop $50 \%$, do 4 kop 57\%, do 5 kop $60 \%$, do 6 kop $64 \%$, do 7 kop 66\%, do 8 kop 68\%, do 9 kop $70 \%$ i do 10 kop 76\%.

69 A. Rutkowski, Warszawski rynek..., s. 76, przy czym są wartości podane jedynie względem pożyczek zabezpieczonych poręczeniem, gdyż autor nie dokonał zestawienia zbiorczego dla wszystkich transakcji.

70 Tenże, Kredyt $\dot{z} y d o w s k i . . .$, s. 268 i n. 
niecałe $42 \%{ }^{71}$, zaś $\mathrm{w}$ sąsiadującej z powiatem warszawskim ziemi łęczyckiej transakcje do 10 grzywien (8 kop) obejmowały 57\% wszystkich zapisów ${ }^{72}$. Zobowiązania kredytowe zawierane przez chłopów z terenów Małopolski i Rusi Czerwonej w 70\% nie przekraczały 5 grzywien $(4 \mathrm{kop})^{73}$. Odmienna sytuacja panowała na mieszczańskich rynkach kredytowych. W późnośredniowiecznym Sieradzu aż 70\% pożyczek mieściło się w granicach do 3 grzywien $(2,5 \text { kopy })^{74}$, w Warcie 67\% umów nie przekraczało 5 grzywien $(4 \mathrm{kop})^{75}$. Natomiast w miastach strefy bałtyckiej w drugiej ćwierci XV stulecia ${ }^{76}$ liczba rent o wartości do 29 grzywien pruskich (10,8 kopy) przedstawiała się w następującej kolejności: Główne Miasto Gdańsk 60\%, Młode Miasto Gdańsk 84\%, Stare Miasto Elblag 27\%, Stare Miasto Torun 28\%, Nowe Miasto Torun $46 \%$, Rewal $15 \%{ }^{77}$. Przeciętna wartość transakcji rentowej ${ }^{78}$ jaka zawierano w tym czasie w wymienionych ośrodkach wynosiła kolejno: Greifswald 9,5 kopy, Główne Miasto Gdańsk 20, Młode Miasto Gdańsk 7, Stare Miasto Elblag 22, Stare Miasto Toruń 38, Nowe Miasto Toruń 15,5 i Rewal $44^{79}$. Mieszczanie wareccy zapisywali w księgach miejskich umowy o przeciętnej wysokości 4,2 kop ${ }^{80}$. Średnia wartość długów Torunian wobec Wrocławian zawartych w I połowie XV wieku wyniosła 28 kop $^{81}$, zaś w odwrotnym stosunku już $61^{82}$. Dużo wyższy poziom prezentował angielski rynek kredytowy, gdzie w latach 1430 1459 notowano transakcje mieszczące się w przedziale 112-123 kopy ${ }^{83}$.

${ }^{71}$ M. Ungeheuer, dz. cyt., s. 87. Dodatkowo warto wspomnieć, iż w przedziale 20-209 grzywien zawarto najwięcej transakcji w ziemi przemyskiej, bo aż 49\%. Powyżej tej wartości znalazło się jedynie ok. 7\% pożyczek.

${ }_{72}$ Z. Morawski, dz. cyt., s. 89. W przedziale 10-30 grzywien (8-24 kop) zawierało się $28 \%$ zapisów, zatem pożyczki do 30 grzywien (24 kop) stanowiły łącznie $85 \%$ ruchu kredytowego.

${ }^{73}$ P. Guzowski, Chłopi i pieniadze..., s. 50. Do wartości 10 grzywien (8 kop) zapisano w sumie ponad $86 \%$ transakcji.

${ }^{74}$ U. Eydkowska-Sowina, dz. cyt., s. 126.

75 A. Bartoszewicz, dz. cyt., s. 119.

${ }^{76} \mathrm{Z}$ wyjątkiem Starego Miasta Elblaga, którego dotyczą dane z lat 1400-1417.

77 Obliczenia własne na podstawie danych w: C. Kardasz, Rynek kredytu..., Aneks: s. 331-332, 336, 348-349, 352-353, 360.

${ }_{78} \mathrm{~W}$ tym przypadku oparta na średniej arytmetycznej.

${ }^{79}$ Obliczenia własne na podstawie danych w: tamże.

${ }^{80}$ Obliczenia własne na podstawie danych w: A. Bartoszewicz, dz. cyt., s. 119; mediana umów wyniosła 3,2 .

${ }^{81}$ Obliczenia własne na podstawie: K. Kopiński, dz. cyt., tabela 20.

${ }^{82}$ Obliczenia własne na podstawie: tamże, tabela 21.

${ }^{83}$ P. Nightingale, Gold, credit..., s. 1087; Przeliczenia z funta na kope groszy na podstawie zawartości srebra; Z. Żabiński, dz. cyt., tabela 18 (s. 52) oraz http://www. lse.ac.uk/economicHistory/Research/Late\%20Medieval\%20Financial\%20Market/ 
Widać więc wyraźnie, że jedynie Nowym Mieście Toruniu zapisywano umowy o podobnej wartości, co w Starej Warszawie. W pozostałych civitates (oprócz Młodego Gdańska i Greifswaldu) przeciętna wartość pożyczki była wyższa od umowy warszawskiej o 20 (Główne Miasto Gdańsk, Stary Elblag) lub 60\% (Stary Toruń i Rewal).

Możemy mówić więc o w miarę jednolitym charakterze (pod względem wartości pożyczek) rynku kredytowego XV-wiecznego powiatu warszawskiego ${ }^{84}$. Kredyt mieszczański, ziemski i żydowski w swojej przeważającej większości (76-88\%) znajdował się w grupie pożyczek do 10 kop. Obok najpopularniejszych, drobnych umów kredytowych, istniał też duży kredyt inwestycyjny, jednakże jego udział w ogólnej strukturze rynku ziemskiego i miejskiego wynosił ok. $23-24 \%$ zapisów oraz zaledwie $12 \%$ pośród pożyczek udzielanych przez Żydów. Skrajne przykłady struktur rynkowych Sieradza i miast strefy południowego Bałtyku (Greifswald, Stary Elblag, Stary Torun, Rewal) pokazuja, jak znaczacy wpływ na układ i obroty kredytowe miała wielkość i ranga ośrodka.

\section{Długość trwania umów kredytowych}

Obok wielkości pożyczek, drugim niezwykle ważnym aspektem funkcjonowania rynku kredytowego jest poznanie długości trwania zobowiązań. Określenie proporcji pomiędzy umowami krótko i długoterminowymi pozwoli nie tylko dokładnie zobrazować dynamikę warszawskiego rynku, ale także oszacować zwiąane ze spłatą kredytu możliwości finansowe mieszczan późnośredniowiecznej Starej Warszawy (wykres 6).

$\mathrm{Na}$ staromiejskim rynku kredytowym dominowały pożyczki krótkoterminowe, których średnia długość wynosiła 7 miesięcy. Mieszczanie XV-wiecznej Starej Warszawy najchętniej zawierali umowy kredytowe na okres półroczny $(13,5 \%)$ i kwartalny $(12,1 \%)$. O zdecydowanej

\footnotetext{
datasheets/datasheetindex.aspx (dostęp: 24 VI 2016). Dziękuję dr. Cezaremu Kardaszowi za informację o istnieniu tych baz danych.

${ }^{84}$ Należy jednak mieć na uwadze, iż obraz ten ze względu na jedynie częściowe opracowanie problemu przez Adama Rutkowskiego, jest obciążony pewnym marginesem błędu i do jego weryfikacji niezbędne są kompleksowe i pełne badania nad działalnością szlachty na rynku pożyczkowym. Warto przypomnieć, że autor skupił się jedynie na sytuacjach, w których miasto było wierzycielem wsi, a zatem w praktyce na niewielkiej części kredytowego rynku szlacheckiego, zob. A. Rutkowski, Warszawski rynek..., s. 70 .
} 
Wykres 6. Umowy kredytowe w zależności od długości trwania (w miesiącach) w Starej Warszawie w latach 1427-1453

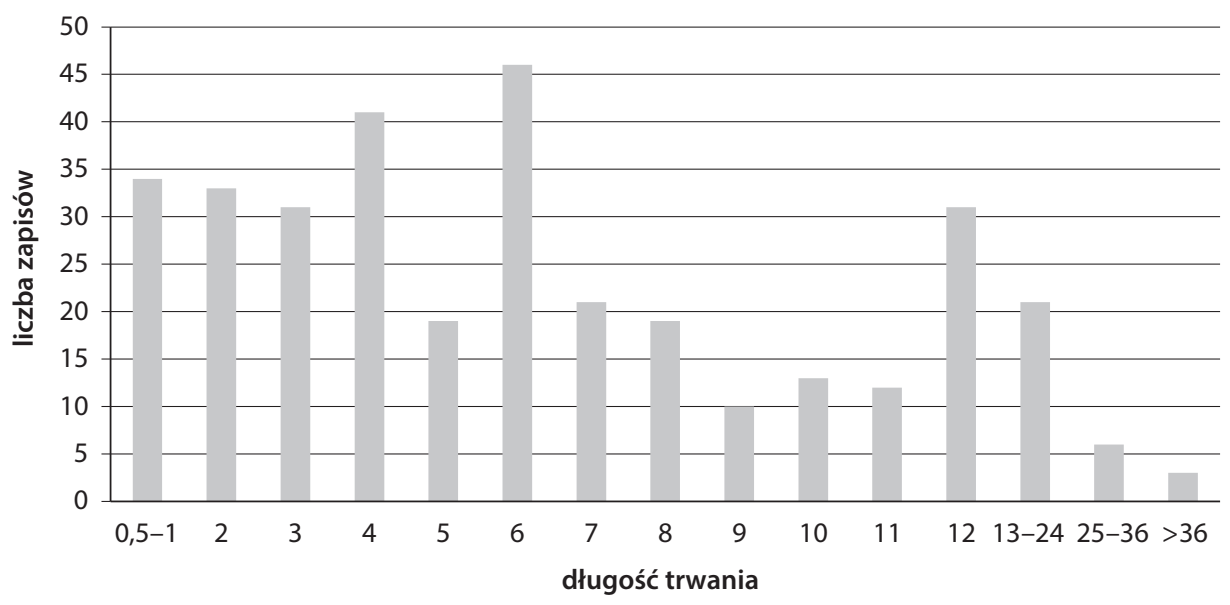

Źródło: KŁMSW, KRMSW

przewadze kredytu krótkoterminowego dodatkowo świadczą przedziały obejmujace pożyczki zawarte do trzech miesięcy, które w sumie stanowią blisko jedna trzecia (29\%) wszystkich umów kredytowych. Pod tym względem zgoła odmienna sytuacja miała miejsce na rynku ziemskim i żydowskim powiatu warszawskiego, gdzie kredyt krótkoterminowy (do 3 miesięcy) stanowił odpowiednio aż $73 \%{ }^{85}$ i $78 \%{ }^{86}$ wszystkich transakcji. Rynkiem bardziej zbliżonym do mieszczańskiego Starej Warszawy pod względem długości trwania pożyczek była ziemia przemyska, w której umowy kredytowe do 3 miesięcy stanowiły 18,5\% ${ }^{87}$. Natomiast jeszcze wyraźniejsze podobieństwa zachodzą przy porównaniu Starej Warszawy z późnośredniowiecznym Sieradzem, gdzie na okres do 3 miesięcy zapisano $40 \%$ transakcji ${ }^{88}$. Za przykład kredytu długoterminowego możemy uznać rynek pożyczek chłopskich, na którym 44\% umów zawierało się w najkrótszym z wyznaczonych przez Piotra Guzowskiego przedziałów wynoszącym 1-5 lat ${ }^{89}$.

\footnotetext{
85 Tamże, s. 78.

${ }^{86}$ A. Rutkowski, Kredyt $\dot{z} y d o w s k i \ldots$, s. 270.

${ }^{87}$ M. Ungeheuer, dz. cyt., s. 87. Dominację kredytu długoterminowego podkreśla liczebność przedziałów wynosząca kolejno: od 3 miesięcy do 1 roku 36,9\% i powyżej 1 roku $34,4 \%$.

${ }^{88}$ U. Łydkowska-Sowina, dz. cyt., s. 129.

${ }^{89}$ P. Guzowski, Chłopi i pieniadze..., s. 62. Górna granicę długości chłopskich zobowiązań kredytowych stanowi okres do 15 lat (96\%), co wydaje się naturalne w świetle faktu, iż przeważająca część umów dotyczyła handlu nieruchomościami.
} 
Zastosowanie szerszych przedziałów czasowych (wykres 7) jeszcze lepiej prezentuje charakter - wyraźnie zdominowanego przez kredyt krótkoterminowy - warszawskiego rynku kredytowego. Ponad połowa (60\%) całości ruchu pożyczkowego zamyka się w okresie półrocznym, natomiast aż 91\% stanowią pożyczki nieprzekraczające $1 \mathrm{roku}^{90}$. Warto zaznaczyć, iż w późnośredniowiecznym Sieradzu do 1 roku zapisano $82 \%$ wszystkich transakcji ${ }^{91}$. Przykłady Starej Warszawy i Sieradza pozwalają wysnuć ostrożny wniosek, że XV-wieczne mieszczańskie rynki kredytowe małych i średnich ośrodków w zdecydowanej większości (80-90\%) opierały się na kredycie krótkoterminowym, który z reguły nie trwał więcej niż 1 rok.

Wykres 7. Umowy kredytowe w zależności od długości trwania (w miesiącach) w Starej Warszawie w latach 1427-1453

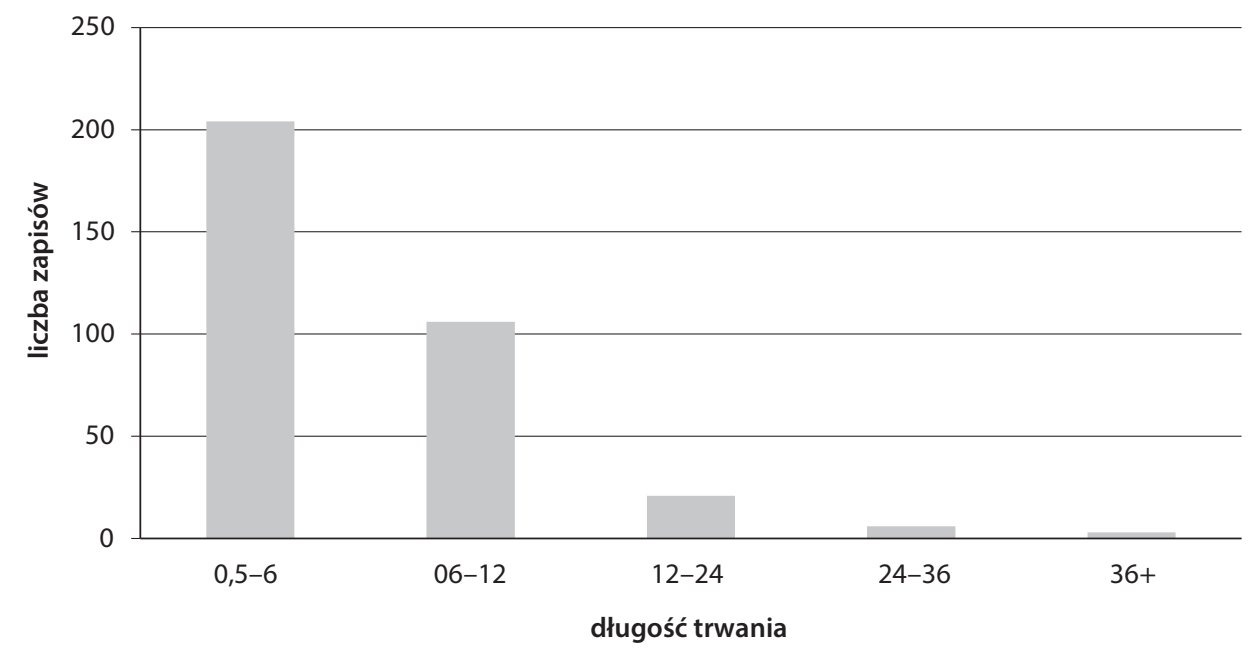

Źródło: KŁMSW, KRMSW

Badając dzieje wymiany pieniężnej w mieście późnego średniowiecza, nie sposób jest pominąć zagadnienie wzajemnych zależności istniejących pomiędzy wysokością i długością transakcji kredytowych (wykres 8).

${ }^{90}$ Do podobnych wniosków (82\% umów zawartych na okres do 1 roku) doszedł także H. Samsonowicz konstruując ogólny obraz stosunków kredytowych w średniowiecznej Polsce (H. Samsonowicz, Local..., s. 57). Również historycy angielscy wskazują na 1 rok jako górna granicę kredytu: J. Kermode, Money and credit in the fifteenth century: some lessons from Yorkshire, „Business History Review” 65, 1991, nr 3, s. 485.

91 U. Eydkowska-Sowina, dz. cyt., s. 129. 
Wykres 8. Umowy zawarte w zależności od czasu trwania kredytu w Starej Warszawie w latach 1427-1453 - średnia i mediana

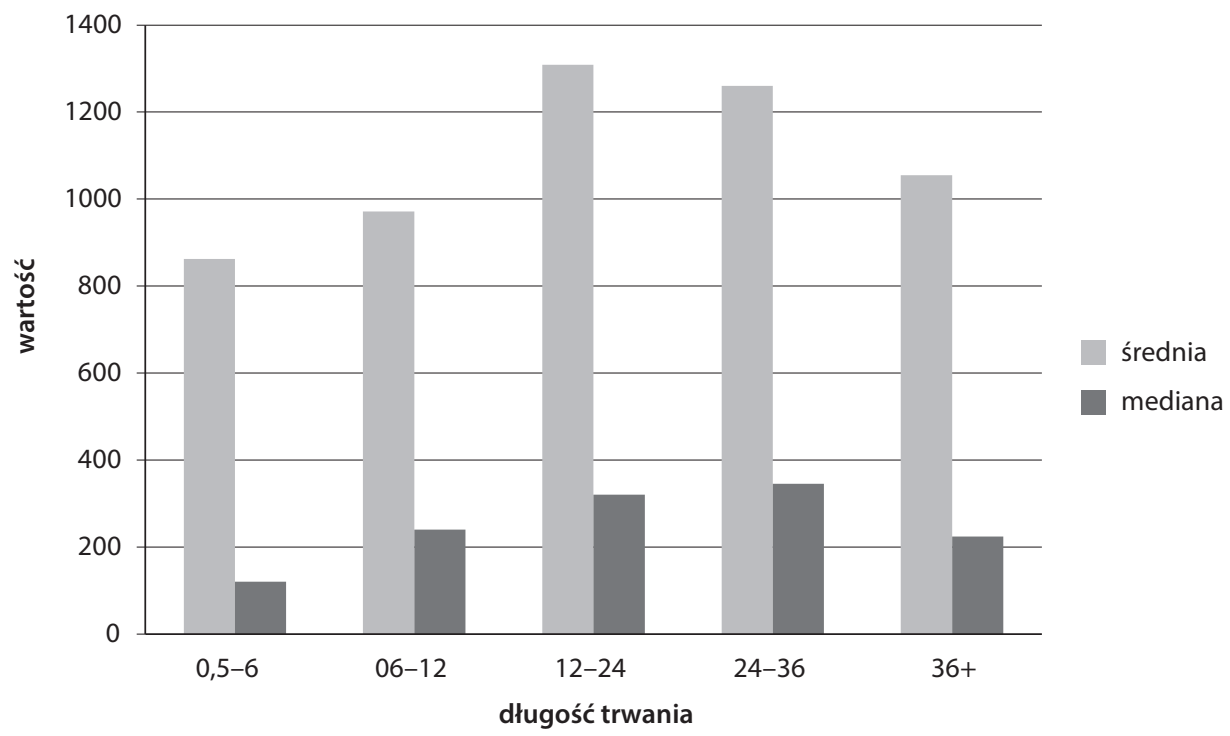

Źródło: KŁMSW, KRMSW

Zarówno średnia, jak i mediana świadczą o istnieniu wzajemnej zależności pomiędzy wysokością i długością pożyczki. Wraz ze wzrostem długości trwania kredytu, systematycznie zwiększała się jego wartość. Na podstawie mediany i średniej arytmetycznej możemy też określić dynamikę tego wzrostu. Pomiędzy medianą dwóch pierwszych przedziałów różnica wynosi 120 gr (w średniej 109 gr), następnie między przedziałem drugim i trzecim zmniejsza się do 80 gr (w średniej rośnie do $337 \mathrm{gr}$ ). Wysokość pożyczek zawartych na 1-2 lub 2-3 lata utrzymuje się już na podobnym poziomie, a różnica $\mathrm{w}$ medianie jest znikoma (zaledwie $25 \mathrm{gr}$ ). Transakcje trwające powyżej 3 lat, zarówno pod względem mediany, jak i średniej są bardzo zbliżone do pożyczek mieszczących się w przedziale 6-12 miesięcy. Dzięki skorelowaniu cech wysokości i długości czasu trwania kredytu, jesteśmy w stanie określić nie tylko wartość typowego długu w każdym z zastosowanych przedziałów, ale przede wszystkim periodyczne możliwości finansowe mieszczan czy też, mówiąc precyzyjniej, wysokość środków, jakie byli w stanie wygospodarować na przestrzeni danego odcinka czasu. Okazuje się zatem, iż w ciagu półrocza mieszkańcy Starej Warszawy prognozowali zgromadzenie nadwyżki w swoich budżetach w wysokości 2 kop groszy. W przypadku kredytu nieco dłuższego (6-12 miesięcy) były to już 4 kopy, zaś powyżej 1 roku przeciętny kontrakt (wg mediany) 
kształtował się na poziomie ponad 5 kop. Niemniej jednak wartość ta ulega niewielkiej zmianie przy kredytach dłuższych niż trzy lata, gdzie odnotowujemy około 4 kop. Zbliżone rezultaty osiagamy po odwróceniu zależności, kiedy to dostrzegamy, iż transakcje do 2 kop trwały przeciętnie pół roku, zaś większe wahały się między okresem 8-14 miesięcy ${ }^{92}$.

Pewnym ułatwieniem w określeniu granic drobnego kredytu konsumpcyjnego i inwestycyjnego jest poznanie siły nabywczej pieniądza, którym obracali warszawscy mieszczanie w pierwszej połowie XV w. (zob. tabela 3).

Na podstawie zapisanych w źródle cen zboża i drewna - uważanych za główne towary handlowe Mazowsza - ale także i pozostałych produktów należy przyjaćc, iż kredyt inwestycyjny (w swojej drobniejszej odmianie) zaczyna się już powyżej 1 kopy groszy. W świetle zapisów handlowych obecnych w księdze ławniczej, umownie za górną granicę drobnego i średniego kredytu inwestycyjnego można uznać wartość $10 \mathrm{kop}^{93}$. Powyżej tej kwoty znajduja się zawierane przez patrycjuszy transakcje kupna-sprzedaży sukna ${ }^{94}$, skór ${ }^{95}$, przypraw $^{96}$ lub dużych ilości drewna ${ }^{97}$, oscylujące już w granicach kilkudziesięciu kop groszy. Zatem najdrobniejszy kredyt konsumpcyjny obejmujący transakcje do 1 kopy stanowił 1/5 całości rynku $(22 \%)^{98}$. Mając też na uwadze fakt, iż 76\% warszawskiego ruchu kredytowego zamyka się w przedziale do 10 kop groszy, możemy stwierdzić, że handel Starej Warszawy nie był wyłącznie zdominowany przez zamożny patrycjat, gdyż w dużej części uczestniczyli w nim przedstawiciele pospólstwa ${ }^{99}$.

92 Dokładny rozkład liczb wynosił kolejno: 8,3 miesięcy dla umów o wartości między 2-3 kopy; 9,6 w przedziale 3-4; 13,8 w zakresie $4-5$; 8 między $5-6$; 13,6 w przedziale 6-7; 9 w zakresie 7-8; 11 między 8-9; 10,5 w przedziale 9-10 oraz 10 miesięcy wobec transakcji większych niż 10 kop.

${ }^{93} \mathrm{Z}$ reguły w tych granicach zawierały się umowy handlowe związane ze zbożem, które było głównym towarem zbytu drobnego kupiectwa warszawskiego; zob. np. KŁMSW, nr 383, 570, 725, 733, 789, 792.

${ }_{94}$ Tamże, nr 99, 260, 261, 264, 1215.

95 Tamże, nr 576, 1061, 1476.

96 Tamże, nr 563, 976.

97 Tamże, nr 60, 274, 295, 345, 367, 743, 1042, 1064, 1444.

98 Adam Rutkowski w stosunku do szlachty powiatu warszawskiego ustanawia granicę kredytu konsumpcyjnego na wartości 30 groszy; A. Rutkowski, Warszawski rynek..., s. 77.

${ }_{99}$ Dobrą ilustracją tego faktu jest umowa handlowa z roku 1440, kiedy to pięciu mieszczan (w tym dwóch rzemieślników: rzeźnik i krawiec), występując coniuncta manu, zakupiło zboże od jednego szlachcica (tamże, nr 570). 
Tabela 3. Ceny w powiecie warszawskim w XV wieku

\begin{tabular}{|c|c|c|c|c|}
\hline Towar & Miara/ilość & $\begin{array}{c}\text { Cena } \\
(\mathrm{w} \text { groszach) }\end{array}$ & Rok & Źródło \\
\hline \multirow{9}{*}{ Żyto } & \multirow{7}{*}{ stóg (acervum) } & 390 & 1434 & KŁMSW, nr 245 \\
\hline & & 300 & 1438 & Tamże, nr 437 \\
\hline & & 370 & 1440 & Tamże, nr 570 \\
\hline & & 180 & 1443 & Tamże, nr 733 \\
\hline & & 210 & 1444 & Tamże, nr 789 \\
\hline & & 300 & 1444 & Tamże, nr 792 \\
\hline & & 150 & 1446 & Tamże, nr 929 \\
\hline & laszt (lastus) & 240 & 1438 & Tamże, nr 442 \\
\hline & korzec (modius) & 2 & 1438 & Tamże, nr 472 \\
\hline \multirow{10}{*}{ Pszenica } & \multirow{3}{*}{ stóg (acervum) } & 110 & 1445 & Tamże, nr 868 \\
\hline & & 120 & 1449 & Tamże, nr 1208 \\
\hline & & 180 & 1451 & Tamże, nr 1320 \\
\hline & \multirow{7}{*}{ korzec (modius) } & 5 & 1425 & $\begin{array}{l}\text { A. Rutkowski, Warszawski } \\
\text { rynek..., s. } 76\end{array}$ \\
\hline & & 2 & 1427 & Tamże \\
\hline & & 6 & 1433 & KŁMSW, nr 228 \\
\hline & & 3,5 & 1438 & A. Rutkowski, op. cit., s. 76 \\
\hline & & 5 & 1446 & Tamże \\
\hline & & 30 & 1448 & KŁMSW, nr 1119 \\
\hline & & 42 & 1450 & Tamże, nr 1266 \\
\hline \multirow{3}{*}{$\begin{array}{l}\text { drewno } \\
\text { (wańczos) }\end{array}$} & \multirow{3}{*}{100 szt. } & 360 & 1436 & Tamże, nr 367 \\
\hline & & 40 & 1438 & A. Rutkowski, op. cit., s. 76 \\
\hline & & 50 & 1446 & Tamże \\
\hline $\begin{array}{l}\text { drewno } \\
\text { (kłody) }\end{array}$ & 100 szt. & 180 & 1422 & A. Rutkowski, op. cit., s. 76 \\
\hline \multirow{7}{*}{ koń } & \multirow{7}{*}{1 szt. } & 100 & 1426 & Tamże \\
\hline & & 180 & 1435 & Tamże \\
\hline & & 360 & 1437 & KŁMSW, nr 411 \\
\hline & & 180 & 1439 & Tamże, nr 538 \\
\hline & & 210 & 1440 & Tamże, nr 584 \\
\hline & & 120 & 1457 & A. Rutkowski, op. cit., s. 76 \\
\hline & & 120 & 1458 & Tamże \\
\hline Kapłon & 1 szt. & 1 & 1433 & Tamże \\
\hline Miód & korzec (modius) & 3 & 1433 & KŁMSW, nr 228 \\
\hline Pieprz & kamień (lapis) & 45 & 1443 & Tamże, nr 730 \\
\hline Śledzie & beczka (alleciata) & 80 & 1446 & Tamże, nr 924 \\
\hline Sól & beczka (alleciata) & 48 & 1446 & Tamże, nr 976 \\
\hline
\end{tabular}




\section{System ratalny}

System ratalny jest nieodłączną częścią każdego rynku kredytowego, zaś stopień jego upowszechnienia świadczy zarówno o poziomie zaawansowania wymiany pieniężnej na danym terenie, jak i zamożności uczestników życia gospodarczego. W XV-wiecznej Starej Warszawie $21 \%$ spośród wszystkich zobowiązań dłużnych opiera się na systemie rat (wykresy 9 i 10). Jeżeli strony decydowały się na podział spłaty, dług najczęściej rozkładano na 2 części (70\%), dopiero potem zaś na $3(23 \%)$. Zdarzały się też pojedyncze przypadki pożyczek rozłożonych na $4^{100}(3 \%)$ i $6^{101}(2 \%)$ rat.

$\mathrm{Na}$ rozłożenie pełnej płatności na raty wpływała przede wszystkim długość umowy kredytowej. Nie było jednak widać zależności zachodzacej pomiędzy liczbą rat a wysokością kontraktu. Nawet duże (kilkudziesięciokopowe) i bardzo duże (kilkusetkopowe) pożyczki były rozkładane najczęściej na zaledwie dwie części.

Powyższe wyniki badań zasadniczo różnią się od ustaleń Mariana Ungeheuera poczynionych dla kredytu szlacheckiego w ziemi przemyskiej w XV w. Autor za główny czynnik warunkujący rozłożenie pożyczki na raty uważał jej wysokość, a nie długość. Wydzielając kredyt drobny (do 20 grzywien/16 kop), średni (od 20 do 200 grzywien/160 kop) i wysoki (powyżej 200 grzywien/160 kop), podaje kolejno dla każdej z grup udział spraw rozłożonych na raty. W tym układzie system ratalny obją kredyt drobny w 4,4\%, średni w 9\% i wysoki w $17,7 \%{ }^{102}$. Podobne badanie sporządzone dla Starej Warszawy przyniosło następujące wyniki: sprawy zaliczane do kategorii kredytu drobnego (do $10 \mathrm{kop} / 12,5$ grzywien) zostały rozłożone na raty w $22 \%$, średniego (10-100 kop/12,5-125 grzywien) w 18\%, wysokiego (powyżej 100 kop/125 grzywien) w 17\%. O ile w przypadku ruchu pożyczkowego ziemi przemyskiej widać dość znaczny wzrost udziału systemu ratalnego w miarę zwiększania się kwoty zobowiąania, o tyle w przypadku Starej Warszawy utrzymuje się on na stałym poziomie obejmując średnio 1/5 transakcji w każdej z grup. Ponadto, widoczne sa dość znaczące różnice w funkcjonowaniu mieszczańskiego i ziemskiego rynku kredytowego. Z jednej strony jest to kilkunastoprocentowa ( $7 \%{ }^{103}$ w ziemi przemyskiej i 21\% w Starej Warszawie) różnica w udziale

${ }^{100}$ KÆMSW, nr 45 (warto zwrócić uwagę, iż rozliczenie nastapi w kamieniach wosku, a nie gotówce), 104, 1250.

101 Tamże, nr 122, 195.

102 M. Ungeheuer, dz. cyt., s. 141 i n.

103 Tamże, s. 141. 
Wykres 9. Liczba rat występujących w pożyczkach w zależności od wysokości kredytów (w kopach) zawartych w Starej Warszawie w latach 1427-1453

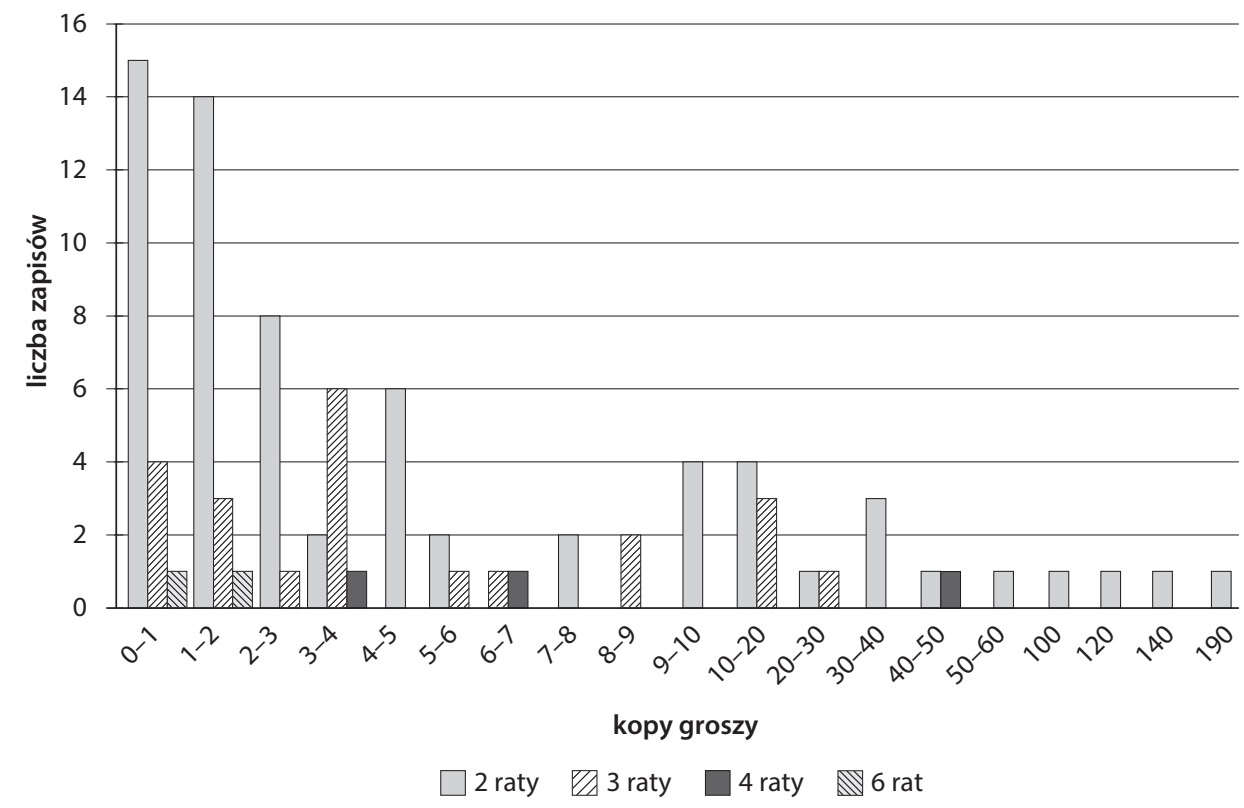

Źródło: KŁMSW, KRMSW

Wykres 10. Liczba rat występujących w pożyczkach w zależności od czasu trwania kredytów (w miesiącach) zawartych w Starej Warszawie w latach 1427-1453

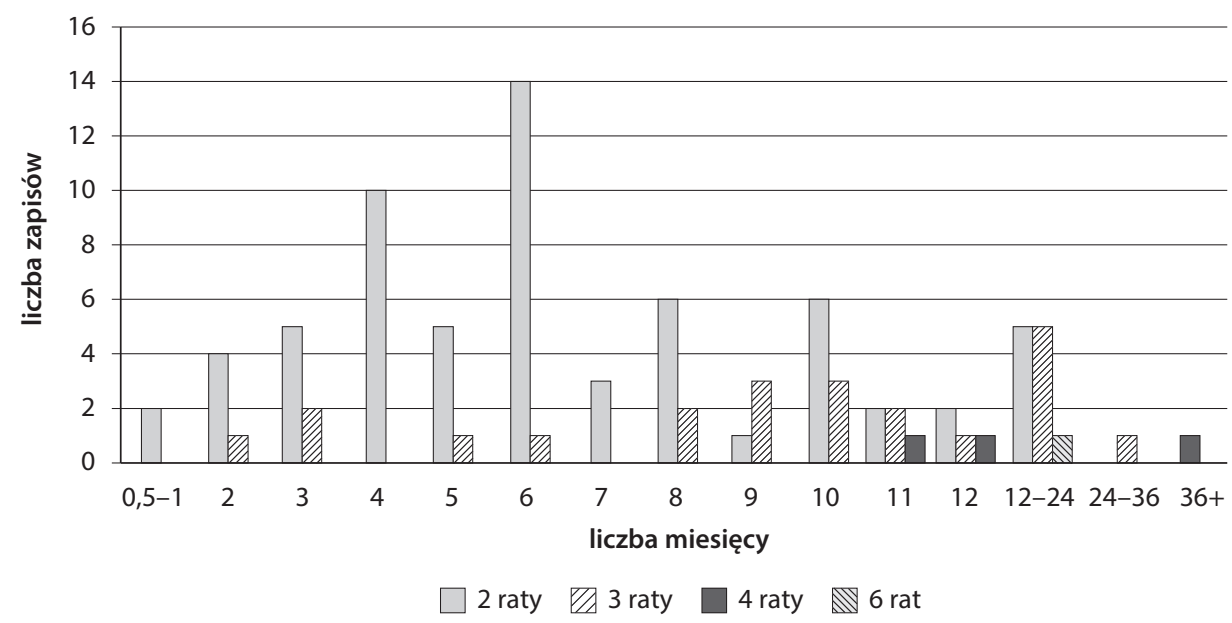

\section{Źródło: KŁMSW, KRMSW}

* Ze względu na brak informacji o dokładnych terminach spłaty poszczególnych rat, w powyższym wykresie pominięta została jedna ze spraw rozłożonych na 6 rat. 
systemu ratalnego w całym obrocie kredytowym. Z drugiej zaś - większa powszechność stosowania spłat ratalnych w przypadku zadłużeń o zróżnicowanej wysokości - szczególnie dostrzegalna w przypadku kredytów drobnych (4,4\% w ziemi przemyskiej do $22 \%$ na rynku warszawskim), co ponownie potwierdza - w przypadku badanej szczegółowo Starej Warszawy - tezę o braku wpływu wielkości kredytu na zastosowanie systemu spłat ratalnych. Należy wyraźnie stwierdzić, iż stosunkowo mniejszy (względem liczby zapisów kredytowych) i uboższy (w kwestii wysokości pożyczek) rynek kredytowy późnośredniowiecznej Warszawy rządził się bardziej zaawansowanymi technikami obrotu pieniądzem, niźli miało to miejsce na większych i zasobniejszych rynkach ziemskich.

Obserwacja wysokości raty stanowi kolejny element pozwalajacy w przybliżeniu określić poziom periodycznych możliwości finansowych przeciętnego gospodarstwa miejskiego ${ }^{104}$ (zob. wykres 11). Mając na uwadze fakt, iż średni czas trwania pożyczki wynosił ok. 7 miesięcy a najczęściej wybieranym systemem ratalnym był podział na dwie spłaty, można zawęzić wnioski do stwierdzenia, że ocena obejmuje okres 3-4 miesięcy.

Największą wiarygodność - głównie ze względu na liczbę zapisów (78) - przedstawia soba pierwszy przedział obejmujący okres do 1 roku włącznie. Pozostałe dwa opieraja się kolejno na 11 i zaledwie 2 zapiskach. Niemniej jednak na podstawie dwóch pierwszych czasokresów widoczny jest wzrost wartości raty wraz z wydłużaniem się czasu trwania umowy, co zostało zauważone także w przypadku średniej wartości całej pożyczki (por. wykres 8). Bez względu na to, czy za podstawę obliczeń przyjmiemy średnia, czy też medianę wartości zapisu kredytowego, wysokość przeciętnej raty z reguły stanowi 33-37\% ogólnej sumy umowy ${ }^{105}$.Natomiast w przypadku kredytu chłopskiego zawieranego w I połowie XV wieku na terenach Małopolski i Rusi Czerwonej, przeciętna rata stanowiła ok. $15 \%$ wartości transakcji ${ }^{106}$.

Dopełnieniem powyższego obrazu funkcjonowania systemu ratalnego będzie zestawienie prezentujące poziom zrównoważenia spłat ratalnych (zob. tabela 4).

${ }^{104} \mathrm{~W}$ przypadku gospodarstw chłopskich zwracał na to uwage P. Guzowski, Chłopi i pieniadze..., s. 55, 62.

105 Przy założeniu, że w całym badanym okresie mediana przeciętnej pożyczki wynosiła 200 groszy, a średnia 976, zaś mediana i średnia raty kolejno 75 groszy (ponad 1 kopę) i 350 (niecałe 6 kop).

${ }^{106}$ P. Guzowski, Chtopi i pieniqdze..., s. 61. 
Wykres 11. Wysokość (w groszach) rat w zależności od czasu trwania umowy na rynku kredytowym w Starej Warszawie w latach 1427-1453 - średnia i mediana

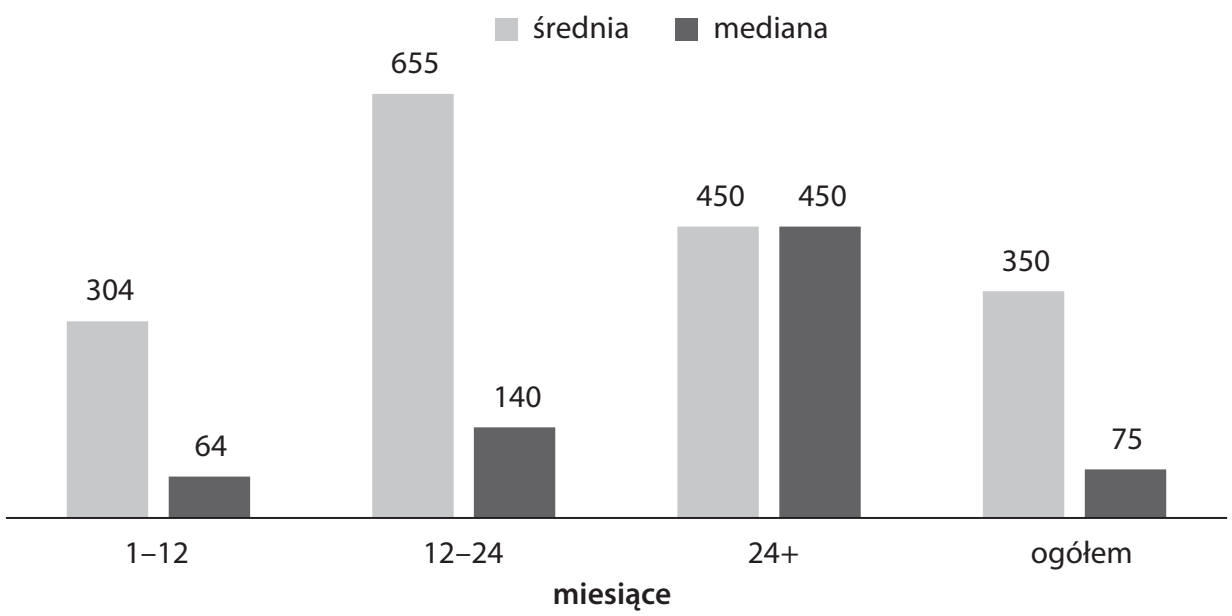

Źródło: KŁMSW, KRMSW

Tabela 4. Proporcje spłat ratalnych na rynku kredytowym Starej Warszawy w latach 1427-1453

\begin{tabular}{c|c|c|c}
\hline Raty & Sprawy & \multicolumn{2}{c}{ \% rat } \\
\hline \multicolumn{2}{c|}{ w liczbach } & równych & nierównych \\
\hline 2 & 66 & 61 & 39 \\
\hline 3 & 23 & 49 & 51 \\
\hline 4 & 3 & 67 & 33 \\
\hline 6 & 2 & 100 & 0 \\
\hline \hline Razem & 94 & 59 & 41 \\
\hline
\end{tabular}

Źródło: KÆMSW, KRMSW

Wśród pożyczek rozłożonych na raty, na warszawskim rynku kredytowym dominowała ogólna tendencja do dzielenia spłaty na równe części ${ }^{107}$. Proporcje pomiędzy zastosowaniem spłat równych i nierównych, zbliżone były jedynie $\mathrm{w}$ grupie kredytów rozłożonych na 3 raty. W pozostałych przypadkach przeważa sytuacja rozkładania pożyczki na równe części, co jest szczególnie dobrze widoczne pośród zobowiązań dzielonych na 4 i 6 spłat.

${ }^{107} \mathrm{Na}$ rynku kredytowym ziemi przemyskiej systemu równych rat użyto w 49,1\% zapisów; M. Ungeheuer, dz. cyt., s. 142. 


\section{Sposób zabezpieczenia pożyczek}

Wszystkie operacje kredytowe wiążą się dla wierzycieli z ryzykiem niemożliwości odzyskania pożyczonych pieniędzy. Zatem aby zapobiec ewentualnej stracie, wypracowano rozmaite sposoby zabezpieczania bardzo zróżnicowanych umów kredytowych. W przypadku Starej Warszawy, prawie połowa (49\%) wszystkich transakcji została opatrzona jakaśs dodatkową formułą asekuracyjną oprócz samego wpisu do księgi (wykres 12). Pozostała część zawiera wyłącznie informacje o wysokości zobowiązania zawartego między stronami.

Jeśli umowa kredytowa zawierała klauzulę zabezpieczenia, najczęściej (w 38\%) dotyczyła ona domu. Taki zapis opatrywano stosownym stwierdzeniem o pierwszeństwie wierzyciela $\mathrm{w}$ egzekucji długu i prawach wobec domus dłużnika ${ }^{108}$. W jednej czwartej spraw (24\%) w przypadku niewywiązania się kredytobiorcy z umowy, przewidywano nałożenie nań dodatkowej kary finansowej ${ }^{109}$ lub utraty dotychczas wpłaconych pieniędzy ${ }^{110}$. Często (w 21\%) używano dość ogólnego pojęcia „pierwszeństwa do dóbr ruchomych i nieruchomych”"11. Zaledwie w kilku przypadkach znajduje się informacja o rodzaju nieruchomości ${ }^{112}$, natomiast brakuje jej w stosunku do dóbr ruchomych, gdzie z reguły nie wyszczególniano co wchodziło w skład tej kategorii $^{113}$. Stosunkowo niewielki odsetek transakcji (10\%) obejmował zapisy dłużne zabezpieczone na ziemi uprawnej (ager et ortus), jaka posiadali mieszczanie extra muros ${ }^{114}$. Jeśli stworzymy odrębną grupę zastawów

${ }_{108} \mathrm{~K}$ KMSW, nr 904 (debet esse primum ad domum); nr 874 (quod si non solverit prefatas peccunias in terminis iam scriptis, extunc dictus Mrowka est primus et principalis supra domum Conusckonis pre ceteris hominibus).

109 Tamże, nr 1163 (sub poena magni iudicij); nr 1267 (sub poena vallata); nr 1082 (sub poena dominorum scabinorum); $\mathrm{nr} 156$ (sub poena XXX solidorum), przy czym w ostatnim przykładzie z pewnością nie chodzi o solidy, lecz szelagi.

110 Tamże, nr 700 (quod si non exsolveret, extunc, quod dedit, hoc deperdetur); nr 903 (quod, si absit, non solverit, subdidit se totidem dampni).

111 Tamże, nr 797 (est primus et principalis super domum ipsius et super bona ipsius tam mobilia, quam immobilia, preter omnes alios creditors).

${ }^{112}$ Najczęściej jest to dom (nr 912, 860, 682), sporadycznie pojawia się informacja o ogrodzie (nr 1394) lub folwarku (nr 1421).

${ }_{113}$ Poza jednym wyjątkiem, kiedy wierzyciel zastrzegł sobie pierwszeństwo do dóbr i res fabricales będących w posiadaniu rzemieślnika Michała Cleinsmeda (nr 693).

${ }^{114} \mathrm{~W}$ księdze występuje pojęcie ortus, które oznacza zarówno ogród jak i zagrodę. $\mathrm{O}$ tym, że była to ziemia służąca uprawie świadczy np. zapis umowy pomiędzy Janem Grzegorzowiczem a Piotrem Lazarowiczem, który to Piotr medietatem orti debet uti cum omnibus fructibus tam diu, donec pretactus Iohannes Gregorij prefatis peccunijs utifruetur (nr 1092). Zapisy obejmujace zabezpieczenie pożyczki jedynie na ogrodzie 
Wykres 12. Sposób zabezpieczenia umów kredytowych w Starej Warszawie w latach $1427-1453$

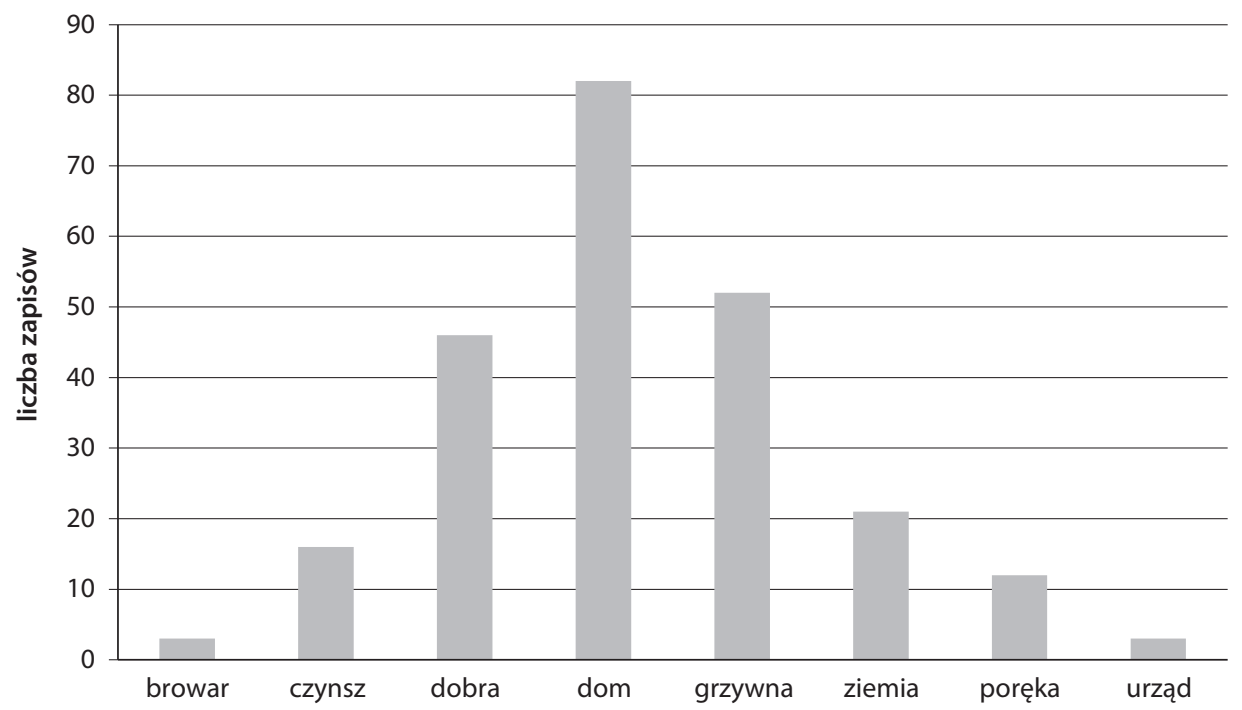

Źródło: KŁMSW, KRMSW

obejmujących wszystkie rodzaje nieruchomości (dom, ogród, browar jak i zapisy na bona mobilitas et immobilitas) okaże się, iż taka forma asekuracji kredytu stanowiła $71 \%$ spośród wszystkich zabezpieczonych pożyczek. Sporadycznie (w 4\% spraw) wspomina się o obowiązku płacenia w wymiarze rocznym dodatkowego czynszu (census) od pożyczonego kapitału. Pokazuje to jak mało popularną forma kredytu na warszawskim rynku były renty, które pojawiaja się na nieco szersza skalę dopiero w latach 40. XV stulecia. Oficjalne (normowane wilkierzem) oprocentowanie tego typu umowy wynosiło $8 \%$ wartości pożyczki (1 grzywna rocznie od $10 \mathrm{kop})^{115}$, co jest cechą charakterystyczną nie tylko na rynkach miast południowego pobrzeża Bałtyku ${ }^{116}$, ale także

występują w 9 na 21 spraw. W pozostałych przypadkach oprócz ogrodu dodatkowo włącza się dom.

${ }^{115}$ KłMSW nr 1437 (debet dare censum secundum laudum civitatis 1 marcam annuatim od pożyczonych10 kop), nr 1369 (domino Petro filio Andree Praga tenetur iusti et veri debiti triginta sexagenas latorum grossorum, a quibus debet solvere censum annuatim, seu singulis annis, per tres marcas iuxta laudum civitatis), nr 1486 (veniens Iacobus Crawse et recognovit, quod tenetur domino Hannus Wylkaw XV sexagenas mediom grossos, a quibus censum dare secundum laudum civitatis [...] 1 marcam cum IIII grossis sine omni dilacione).

$116 \mathrm{~W}$ miastach bałtyckich od połowy XIV wieku obserwujemy systematyczne obniżanie stopy oprocentowania z 10\% do najczęściej 8,33\%, najtańsze renty $(6,66 \%)$ 
i innych europejskich ośrodków ${ }^{117}$. Stosunkowo rzadko (5\%) przy zawieraniu umowy wymagano obecności poręczyciela (fideiussor). W trzech przypadkach (1\%) w roli zastawu wykorzystano browar ${ }^{118}$. Podobnie w trzech sprawach jako podstawa zabezpieczenia kredytu pojawia się pełniony urząd - w tym przypadku wójtostwo ${ }^{119}$.

Pod względem rodzajów zabezpieczeń kredytu rynek warszawski zasadniczo nie odbiegał od innych rynków mieszczańskich i ziemskich. Różnice polegały głównie na powszechności użycia wybranych formuł asekuracyjnych pożyczki. W okresie późnego średniowiecza zarówno w Starej Warszawie, Sieradzu ${ }^{120}$, Warcie ${ }^{121}$ i miastach południowego Bałtyku $^{122}$ najczęściej jako formę zabezpieczenia kredytu stosowano zastaw nieruchomości - głównie domu. W przypadku rynków ziemskiego i żydowskiego powiatu warszawskiego, decydującą rolę odgrywało poręczenie stanowiące ponad $60 \%$ wszystkich zabezpieczeń ${ }^{123}$.

były dostępne w Starym Mieście Toruniu i Rewlu; zob. C. Kardasz, Rynek kredytu..., s. 204-205, 209-210, 211, 216-218, 220, 224-225, 227, 232-236, 238. Oprocentowanie rent gruntowych analizował także H. Samsonowicz, Badania nad kapitałem..., s. 52-69; B. Lesiński, dz. cyt., s. 181-194; Dane z Europy Zachodniej zob. J. Zuijderduij, dz. cyt., s. 283-285.

117 J.L. van Zanden, J. Zuijderduij, T. de Moor, dz. cyt., s. 17-19.

118 Dwukrotnie uczynił to Paulus Bogatko, wydzierżawiając browar w roku 1449 i 1453 (KłMSW, nr 1214, 1465). Podobnie postapił w 1450 r. Jan Pielgrzym wójt Starej Warszawy, który zaciagnięte 60 kop zapisał nie tylko na browarze, ale też i innych posiadanych nieruchomościach (nr 1298).

${ }^{119}$ W 1443 r. Jan Hafftar na poczet zaciagniętych u Bartosza Verhynsta 19 kop indaviavit advocaciam in Zisskowo et privilegium sibi dedit super eandem advocaciam (tamże, nr 719). Kolejny zastaw wójtostwa miał miejsce w 1452 r. i dotyczył urzędu warszawskiego, kiedy to borykający się z kłopotami finansowymi Jan Pielgrzym invadiavit privilegium super advocaciam za $10 \mathrm{kop}$ (tamże, nr 1413). Więcej o wójtach warszawskich zob. S.M. Szacherska, Wójtowie dziedziczni Starej Warszawy w XV i XVI wieku, w: Społeczeństwo Polski średniowiecznej. Zbiór studiów, t. 1, Warszawa 1981, s. 291-346. Wójtostwo (niestety, nie wiadomo, jakie) wchodziło w skład zastawu, jakim Venczeslavus molendinator opatrzył pożyczone od swojego teścia Świętosława Chadupko 16 kop i 10 groszy. Oprócz urzędu Więcesław zastawił też swój młyn, ogrody i łąki, z których korzyści miał od tej pory czerpać teść.

${ }^{120}$ U. Łydkowska-Sowina, dz. cyt., s. 130.

121 A. Bartoszewicz, dz. cyt., s. 122-123.

122 Transakcje opatrzone zastawem nieruchomości stanowiły ponad połowę (58\%) ogólnej sumy zapisów kredytowych; R. Czaja, Kredyt pieniężny..., s. 7; zob. także C. Kardasz, Rynek kredytu..., s. 45-48. Nieco odmienna sytuacja panowała w Gdańsku 2. poł. XV w., gdzie nad dobrami nieruchomymi zdecydowanie przeważały ruchomości (ubrania, rozmaite towary kupieckie, klejnoty i statki); H. Samsonowicz, Badania nad kapitatem..., s. 80.

${ }^{123}$ A. Rutkowski, Warszawski rynek..., s. 73, 75; tenże, Kredyt żydowski..., s. 275. Warto zwrócić uwagę na dość znaczącą różnicę w sposobie zabezpieczania pożyczek 
Wykres 13. Średnia arytmetyczna i mediana wartości pożyczek (w groszach) zaciąanych w Starej Warszawie w latach 1427-1453 w zależności od sposobu ich zabezpieczenia

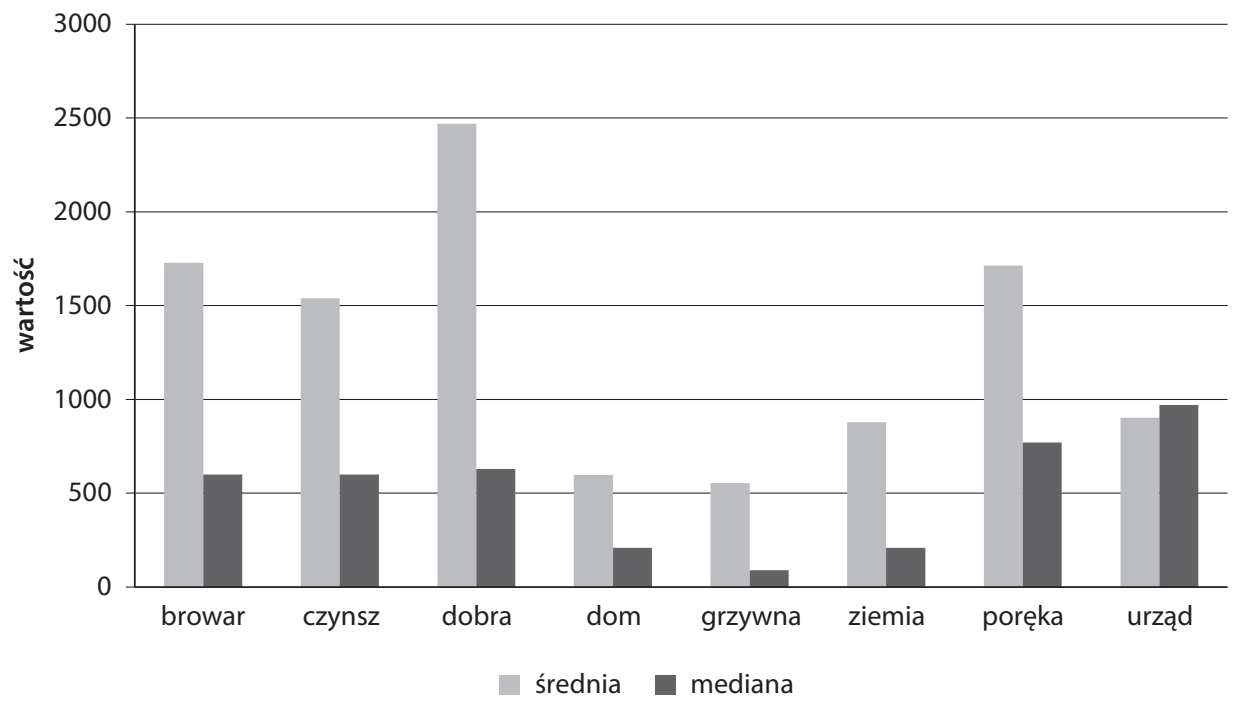

Źródło: KŁMSW, KRMSW

Inaczej niż w powiecie warszawskim, asekurowano pożyczki w ziemi przemyskiej i łęczyckiej, gdzie opierano się głównie na różnych formach zastawu nieruchomości ${ }^{124}$.

Znając sposoby zabezpieczania kredytu, warto się jeszcze przyjrzeć przeciętnej wysokości pożyczek osiąganej w każdej z grup (wykres 13). Okazuje się, iż w stosunku do kredytu drobniejszego (ok. 2 kop) wystarczyła klauzula obciążenia dłużnika dodatkową kara pieniężną (magna poena). Nieco większe pożyczki (3-4 kopy) zabezpieczano już na nieruchomościach - domu lub ogrodzie. Z kolei kredyt średni i duży (powyżej 10 kop) głównie asekurowano zapisem na bona mobilitas et immobilitas, niekiedy też dodatkowo wymagając poświadczenia osób trzecich ${ }^{125}$.

żydowskich we Wrocławiu i powiecie warszawskim. W świetle wrocławskich spisów zastawów, długów i mienia żydowskiego z 1453 r., najczęstszą formą zabezpieczenia kredytu żydowskiego był (w odróżnieniu do powiatu warszawskiego) zastaw rzeczowy; zob. szerzej M. Goliński, Wroctawskie spisy..., s. 23-35.

${ }^{124} \mathrm{~W}$ ziemiach przemyskiej i łęczyckiej zastawy nieruchomości wynosiły kolejno $48,7 \%$ i $31 \%$, co w porównaniu do powiatu warszawskiego (3-4\%) pokazuje, iż nawet między sassiadującymi rynkami (ziemia łęczycka i powiat warszawski) mogą istnieć znaczące rozbieżności; zob. M. Ungeheuer, dz. cyt., s. 59; Z. Morawski, dz. cyt., s. 55; A. Rutkowski, Warszawski rynek..., s. 75; tenże, Kredyt żydowski..., s. 275.

${ }^{125}$ Warto zaznaczyć, iż sprawy opatrzone klauzula poręczenia z reguły nie wiązały się z dodatkowymi zabezpieczeniami i występowały niejako samodzielnie. Odwrotna 
Powyżej wartości 10 kop znajdowały się także umowy kupna/sprzedaży rent, których przeciętna wartość (25,6 kopy wg średniej) była niższa bądź zbliżona do wysokości zapisów rentowych miast strefy południowego Bałtyku ${ }^{126}$.

\section{Terminy zaciągnięcia i spłaty pożyczek}

Stosunkowa duża kompletność i szczegółowość materiału zawartego w warszawskiej księdze ławniczej, pozwala w zdecydowanej większości umów kredytowych wyznaczyć ich dokładny początek (79\%) i koniec (74\%). Na podstawie tych informacji możliwym staje się określenie sezonowości zaciagania i spłacania pożyczek (zob. wykres 14), a tym samym momentów największego zapotrzebowania na gotówkę (wykres 15).

Wykres 14. Miesiące zaciagnięcia i spłaty pożyczek w Starej Warszawie w latach 1427-1453

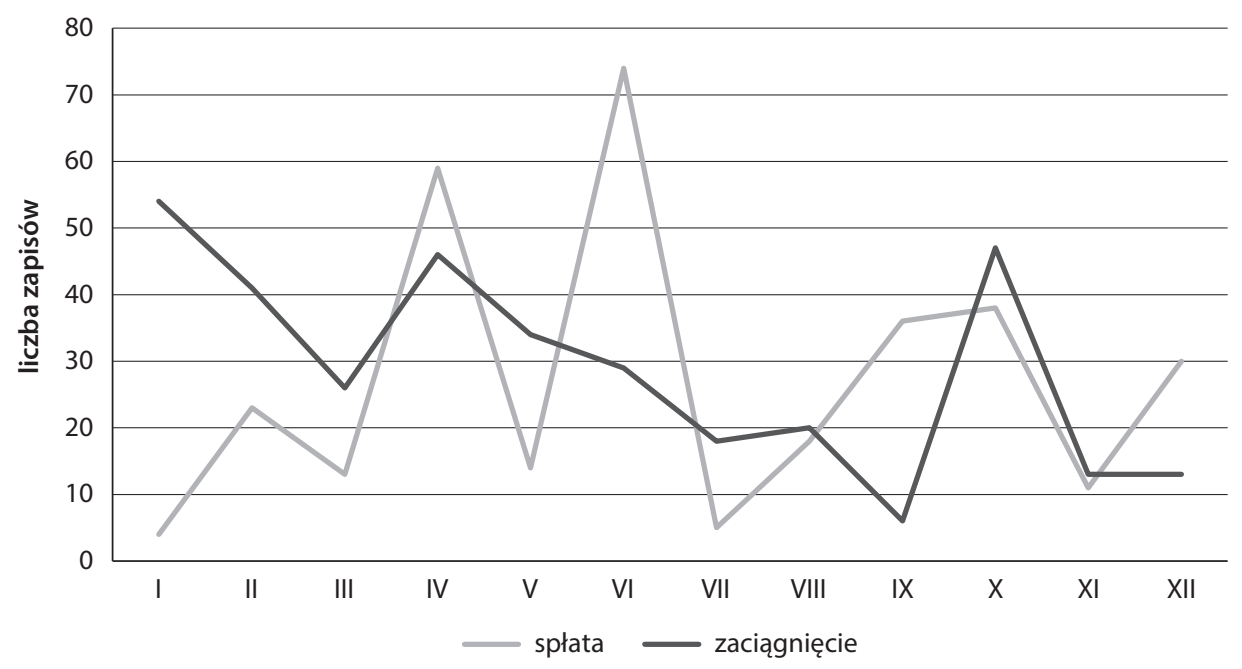

Źródło: KŁMSW, KRMSW

sytuacja miała miejsce w przypadku ogólnej kategorii dóbr ruchomych i nieruchomych, lub też zapisów na domu, ogrodzie, browarze czy nawet wójtostwie, kiedy to w jednej sprawie znajdowały się dwa lub trzy obiekty służące zabezpieczeniu, np. jeden z zastawów wójtostwa w roku 1452 połączono z rocznym czynszem (KłMSW, nr 1413), natomiast w roku 1450 Jan Pielgrzym zapisał pożyczkę jednocześnie na kamienicy, domu (drewnianym?), ogrodzie i browarze (tamże, nr 1298).

${ }^{126}$ Większą wartość osiagały zapisy rentowe w Starym Mieście Toruniu, zaś podobną w Głównym Mieście Gdańsku, Starym Mieście Elblagu i Nowym Mieście Toruniu. Zob. szerzej na ten temat przy okazji rozważań dotyczących wykresu 5. 
Wykres 15. Wartość (w groszach) umów kredytowych zawartych w Starej Warszawie $\mathrm{w}$ latach 1427-1453 w zależności od miesiąca zapisu

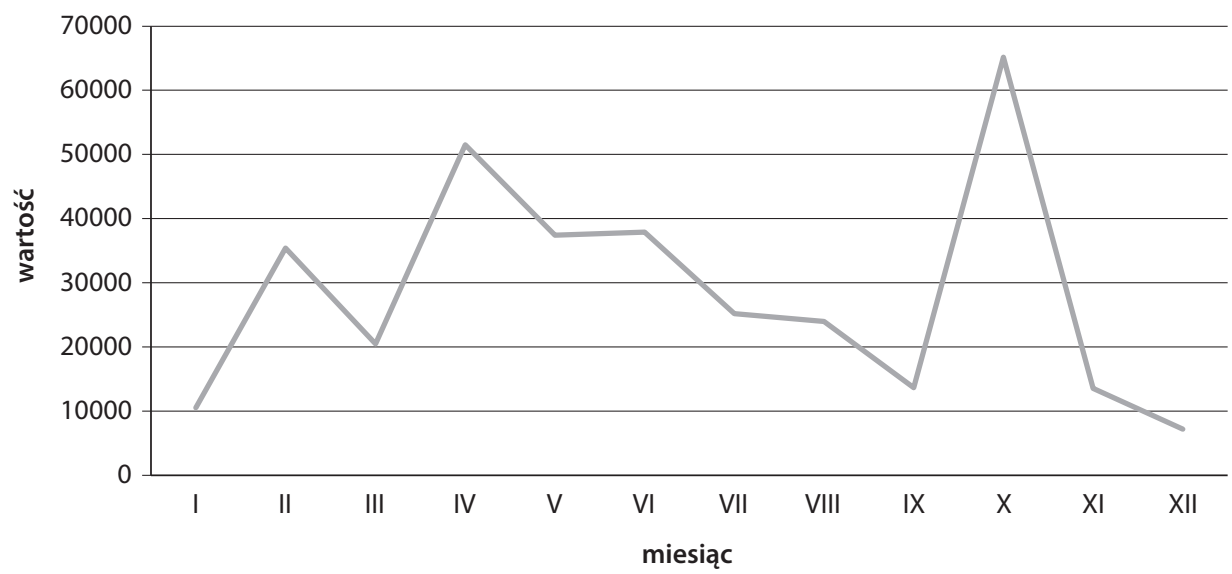

Źródło: KŁMSW, KRMSW

W przypadku terminów zaciagania pożyczek dostrzegalne są trzy wyraźne szczyty. Pierwszy przypada na okres przednówka (styczeń i luty) z jednej strony wiązanego często z niedoborem żywności i gotówki, zaś z drugiej - przygotowaniem do wiosennego jarmarku i handlu spławnego Wisła (ad primam aquam $)^{127}$. Dwa kolejne szczyty przypadaja na kwiecień i październik. Niemalże identyczny rytm wpisów do ksiag sądowych możemy zaobserwować w późnośredniowiecznym Przeworsku ${ }^{128}$, Sieradzu ${ }^{129}$, Przemyślu ${ }^{130}$, Radziejowie ${ }^{131}$, Szadku $^{132}$, Kazimierzu $^{133}$, Chrzanowie ${ }^{134}$, Lublinie ${ }^{135}$ i Bochni ${ }^{136}$. Zbieżność datacji

${ }^{127}$ H. Samsonowicz, Warszawa..., s. 29. Na przednówku zawarto ponad $60 \%$ wszystkich znajdujących się w księdze umów kupna-sprzedaży zboża (KłMSW, $\mathrm{nr} 228,245,383,437,442,472$, 570, 733, 789, 792, 868, 929, 1119, 1208, 1266). Zapisy zwiazane z terminem ad primam aquam dotycza przede wszystkim handlu spławnego drewnem. Z reguły strony transakcji umawiają się na dostarczenie towaru lub pieniędzy „na pierwszą wodę” w Gdańsku (tamże, nr 21, 60, 274, 278, 291, 345, 367, 484, 1002, 1042, 1444). Zob. także M. Bogucka, H. Samsonowicz, dz. cyt., s. 226 i n.

${ }^{128}$ A. Bartoszewicz, Czas $w$ małych miastach. Studium z dziejów kultury umystowej późnośredniowiecznej Polski, Warszawa-Pułtusk 2003, Aneks, Rys. 1.

129 Tamże, Rys. 2.

130 Tamże, Rys. 3.

131 Tamże, Rys. 4.

132 Tamże, Rys. 5.

133 Tamże, Rys. 6.

134 Tamże, Rys. 9a.

135 Tamże, Rys. 10.

136 Tamże, Rys. 11. 
spraw pokazuje, iż system trzech szczytów (na przednówku, wiosna i jesienia) był charakterystyczny dla polskich średnich i małych miast okresu późnego średniowiecza ${ }^{137}$.

Natomiast w stosunku do terminów spłat umów kredytowych możemy mówić o czterech szczytach: wiosennym (kwiecień), letnim (czerwiec), jesiennym (wrzesień i październik) oraz zimowym w grudniu. W literaturze już wielokrotnie zwracano uwagę na ścisły związek małych i średnich miast $\mathrm{z}$ ich rolniczym zapleczem ${ }^{138}$. W przypadku Starej Warszawy zbieżność terminów zaciagania i spłat pożyczek ${ }^{139}$ z rynkami kredytowymi powiatu warszawskiego ${ }^{140}$, ziemi przemyskiej ${ }^{141}$ oraz późnośredniowiecznego Sieradza ${ }^{142}$ i Warty ${ }^{143}$, potwierdza powiazanie Antiquae Varsoviae z otaczajacym miasto regionem ${ }^{144}$. Cykl agrarny nie był jednak jedynym czynnikiem warunkującym organizację rynku kredytowego. Ważną rolę pełniły doroczne jarmarki, które w Starej Warszawie wypadały właśnie w kwietniu i czerwcu ${ }^{145}$. Ustalając dokładny dzień spłaty, strony z reguły wybierały momenty mające szczególne znaczenie w życiu społeczności - dużą popularnością cieszyły się np. dni patronów warszawskich kościołów: św. Jerzego (23 kwietnia) i św. Jana Chrzciciela (24 czerwca), które dodatkowo pokrywały się

${ }_{137}$ Podobne stanowisko zajmuja M. Bogucka, H. Samsonowicz, dz. cyt., s. 194 i n.

138 A. Rutkowski, Warszawski rynek..., s. 71-73; M. Bogucka, H. Samsonowicz, dz. cyt., s. 181; H. Samsonowicz, Warszawa..., s. 9-31; E. Koczorowska-Pielińska, Struktura gospodarczo-spoteczna..., s. 303-310.

${ }_{139}$ Obserwowane sąniewielkie, zreguły miesięczne przesunięcia szczytów zaciagania i spłat pożyczek. Niemniej jednak z punktu widzenia pór roku wyniki są bardzo zbliżone.

140 A. Rutkowski, Warszawski rynek..., s. 77 i n.; tenże, Kredyt żydowski..., s. 270.

141 Wystarczy porównać zestawienie terminów zaciagania pożyczek względem pór roku w ziemi przemyskiej (wiosna 27,8\%, lato 13,5\%, jesień $15 \%$, zima 29,3\%) ze Stara Warszawa (wiosna 31\%, lato 19\%, jesień 19\%, zima 31\%). M. Ungeheuer, dz. cyt., s. 152.

${ }_{142}$ U. Łydkowska-Sowina, dz. cyt., s. 128.

143 A. Bartoszewicz, Warta..., s. 120-121.

${ }^{144}$ Nieco odmienny obraz przedstawił H. Samsonowicz, Local..., s. 56 prezentując następujący układ terminów spłaty kredytów w średniowiecznej Polsce: zima 39\%, wiosna $22 \%$, lato $12 \%$ i jesień $14 \%$. W Starej Warszawie sytuacja przedstawiała się nieco inaczej, gdyż zimą spłacano $18 \%$ umów, wiosną $26 \%$, latem $30 \%$ i jesienią $26 \%$.

${ }^{145} \mathrm{Na}$ znaczenie jarmarków zwracali uwagę M. Ungeheuer, dz. cyt., s. 153; A. Rutkowski, Warszawski rynek..., s. 77; U. Łydkowska-Sowina, dz. cyt., s. 129; R. Czaja, Gospodarcze znaczenie..., s. 121-132; A. Bartoszewicz, Czas w matych..., s. 234-241. Należy wyraźnie zwrócić uwagę na fakt, iż Stara Warszawa jarmarki w trzech szczytowych terminach formalnie otrzymała dopiero w $1461 \mathrm{r}$. Miały się one rozpoczynać w druga niedzielę po Wielkanocy, 1 sierpnia i 15 października. Odnosząc ten fakt do danych zawartych w wykresie 13, można wysnuć przypuszczenie, iż dokument z 1461 r. jedynie legalizował, czy też bardziej formalizował istniejący już zwyczaj. O jarmarkach warszawskich szerzej zob. H. Samsonowicz, Warszawa..., s. 27-30. 
z terminami jarmarków ${ }^{146}$. Na spłatę kredytu w dniu s. Johannis Baptiste umówiono aż 1/5 wszystkich transakcji, zaś do festi s. Georgii zapisano $13 \%$ umów. Jesienny szczyt spłat pożyczek wiązał się głównie z dniami św. Michała ${ }^{147}$ (29 września - 8\% spłat) i św. Jadwigi (15 października - 11\%), a także przypadającym w tym czasie ostatnim, dorocznym iudicium magnum bannitum ${ }^{148}$ i zbliżającym się dniem św. Marcina (11 listopada ${ }^{149}$ ), w którym dokonywano rozliczeń ze skarbem książęcym. Czwarty, ale wyraźnie już mniejszy zimowy szczyt finalizacji zobowiązań pieniężnych, dotyczył przede wszystkim festi Nativitatis Christi (25 grudnia), kiedy to uregulowano $7 \%$ spłat $^{150}$.

Najpopularniejsze terminy zaciagania pożyczek wyraźnie łączą się z momentami największego zapotrzebowania na gotówkę. Stały popyt na pieniądz trwał w zasadzie przez pierwsza połowę roku - od lutego do czerwca, a więc w sezonie handlowym (wykres 14). Bardzo istotna obserwacja jest stabilność tegoż popytu, która pokazuje systematyczną aktywność gospodarczą mieszczan w tym okresie. Drugi szczyt zapotrzebowania na gotówkę wiąże się z początkiem jesieni (październik), a zatem nie tylko nadchodzącym się okresem płacenia czynszów in die sancti Martini, ale również z przygotowaniami do trudnego czasu zimowego.

\section{Podsumowanie}

Z analizy warszawskiego rynku kredytowego wyłania się obraz średniego miasta, którego gospodarka od drugiej połowy lat 30. systematycznie zaczyna przyspieszać, a civitas Antiquae Varsoviae wchodzi wraz ze swymi obywatelami w okres prosperity przełomu dwóch epok, i co warto zaznaczyć, nie widać w niej śladów późnośredniowiecznego kryzysu gospodarczego ${ }^{151}$. Rozwój ekonomiczny dostrzegamy przez pryzmat

146 Organizowanie jarmarków w terminach, na które również przypadały miejskie odpusty parafialne było zwyczajem niezwykle popularnym wśród małych i średnich ośrodków, wspomina o tym A. Bartoszewicz, Czas w matych..., s. 238.

147 Jeszcze większą rolę niż w Starej Warszawie odgrywał dzień św. Michała w Płocku; tamże, s. 176 i n.

${ }_{148} \mathrm{~K}$ MSW, nr 1180 (in magno iudicio primo affuturo, videlicet in autumpno).

149 A. Rutkowski, Kredyt pieniężny..., s. 270; A. Bartoszewicz, Czas w matych..., s. $175 \mathrm{n}$.

150 Termin Bożego Narodzenia cieszył się porównywalną popularnością także w Przemyślu i Kazimierzu; tamże, s. 171.

${ }^{151}$ Szerzej na temat dyskusji nad obecnością kryzysu gospodarczego na ziemiach polskich w późnym średniowieczu pisał P. Guzowski, Kryzys gospodarczy późnego 
kilku istotnych wskaźników. Prawie dwukrotnie zwiększa się liczba zapisów kredytowych i aż ośmiokrotnie ich wartość. Aktywizacja obejmuje zarówno patrycjat jak i pospólstwo, które coraz częściej i liczniej pojawia się na rynku kredytowym. Gospodarka warszawska nie jest tak jednoznacznie zdominowana przez waska grupę kupiectwa - jak możemy to obserwować w rozwiniętych miastach hanzeatyckich, lecz odznacza się również znaczącym udziałem kredytu średniego i małego. Rynek kredytowy późnośredniowiecznej Starej Warszawy w swojej przeważającej części opierał się na pożyczkach niewielkich (mediana 2 kopy) i krótkoterminowych (przeciętnie trwających 7 miesięcy). Ze względu na ograniczenia źródłowe trudno jest ustalić dokładne proporcje między drobnym kredytem konsumpcyjnym a inwestycyjnym i precyzyjnie wykazać sferę inwestycji pożyczonych pieniędzy. Jednak pewnych przesłanek dostarcza nam różnorodność spraw zapisywanych w księgach warszawskich, gdzie często dostrzegamy mieszczan biorących udział w działach majątkowych ${ }^{152}$, drobnym handlu ${ }^{153}$, czy też kupnie nieruchomości ${ }^{154}$. Za handlowym charakterem aktywności Warszawian może przemawiać sezonowość zapisów, która dość jednoznacznie wskazuje na związek Starej Warszawy ze swoim rolniczym zapleczem.

Znacznie większy udział w rynku pożyczkowym przypadał bardzo aktywnemu gospodarczo (szczególnie od lat 30. XV w.) patrycjatowi. Zaangażowani $\mathrm{w}$ handel ponadregionalny, warszawscy mercatores swoją kupiecką działalność opierali o sumy znacznie większe, z reguły przekraczające wartość kilkudziesięciu lub nawet kilkuset kop. Ważnym elementem obrazującym możliwości finansowe staromiejskich rodzin była zarówno obserwacja wysokości transakcji w zależności od czasu jej trwania, jak i sposób funkcjonowania sytemu ratalnego.

średniowiecza czy kryzys historiografii?, RDSG 68, 2008, s. 173-193. Głos zabierali także M. Dygo, Czy w Polsce średniowiecznej byt kryzys gospodarczy?, PH, t. 80, 1989, s. 752-764; M. Małowist, Zagadnienie kryzysu feudalizmu w XIVi XV wieku w świetle najnowszych badań, KH 60, 1953, s. 86-104; J. Wyrozumski, Czy późnośredniowieczny kryzys feudalizmu dotknat Polskę?, w: Homines et societas..., s. 103-113.

152 KłMSW, nr 301, 581, 811, 865, 987, 1005, 1050, 1121, 1161, 1206, 1276, 1332, 1362, 1381, 1440, 1494. Zob. rozważania o demografii i poziomie zamożności rodzin warszawskich: P. Łozowski, Demografia rodziny mieszczańskiej w Starej Warszawie w pierwszej połowie XV wieku, „Przeszłość Demograficzna Polski” 32, 2013, nr 4, s. $1-18$.

${ }^{153} \mathrm{~K}$ MMSW, nr 274, 345, 471, 538, 563, 614, 733, 743, 794, 868, 877, 929, 976. Więcej o kategoriach i poziomie aktywności gospodarczej mieszczan warszawskich zob. P. Łozowski, Pieniqdze bogaczy..., Tabela 5, s. 178.

154 KŁMSW, nr 307, 441, 529, 537, 708, 711, 885, 938, 966, 1113, 1425. 
Analiza wykazała, iż mieszczanie już na przestrzeni półrocza byli w stanie wygospodarować około 2 kop groszy, natomiast w okresie 12 miesięcy 4 kopy. Ponadto w przeciagu kwartału gromadzili środki pokrywajace $37 \%$ wartości pożyczki, co $\mathrm{w}$ połaczeniu z krótkim okresem kredytowania, wydaje się świadczyć o dobrej kondycji ekonomicznej mieszkańców późnośredniowiecznej Starej Warszawy.

Trudno jednoznacznie stwierdzić, czy otrzymane wyniki powinniśmy traktować jako reprezentatywne i miarodajne również dla innych miast zaliczanych w późnym średniowieczu do kategorii średnich (szczególnie mając na uwadze brak podobnych studiów nad innymi zbliżonymi wielkością miastami). Pomimo tego, że Warszawa należała przecież do grupy civitates et oppida secundo ordini, to należy pamiętać, iż stanowiła zaledwie 1 z liczby 88 podobnych ośrodków ${ }^{155}$. Dla części z nich zachowały się księgi sądowe, zatem najważniejszym postulatem płynącym z powyższych badań jest zachęta do dalszego rozszerzania podstawy komparatystycznej. Przemyślany dobór chronologiczno-terytorialny źródeł pozwoliłby na przeniesienie wnioskowania już na skalę makro i szerszego odniesienia się do koniunktury gospodarczej panującej w danym regionie, czy też części państwa.

\section{Bibliografia}

\section{Źródła}

Ksiega radziecka miasta Starej Warszawy, t. 1: (1447-1527), wyd. A. Wolff, Wrocław-Warszawa-Kraków 1963.

Ksiegi tawnicze miasta Starej Warszawy z XV w., t. 1, Księga nr 525 z lat 1427-1453, wyd. S. Ehrenkreutz, Warszawa 1916.

\section{Opracowania}

Bartoszewicz A., Czas w matych miastach. Studium z dziejów kultury umystowej późnośredniowiecznej Polski, Warszawa-Pułtusk 2003.

Bartoszewicz A., Handel sola na Mazowszu w XV i XVI wieku, „Rocznik Mazowiecki” 18, 2006, s. 47-62.

Bartoszewicz A., Warta. Spoteczeństwo miasta w II połowie XV i na poczqtku XVI wieku, Warszawa 1997.

Biskup M., Handel wiślany w latach 1454-1466, „Roczniki Dziejów Społecznych i Gospodarczych" 14, 1952, s. 165-202.

${ }^{155}$ M. Bogucka, H. Samsonowicz, dz. cyt., s. 119. 
Biskup M., Z problematyki handlu polsko-gdańskiego drugiej połowy XV wieku, „Przegląd Historyczny” 45, 1954, z. 2-3, s. 390-407.

Bogucka M., Samsonowicz H., Dzieje miast i mieszczaństwa w Polsce przedrozbiorowej, Wrocław 1986.

Chudoba T., Warszawski rynek zbożowy w XVI wieku, „Rocznik Warszawski” 6, 1967, s. 15-47.

Chudoba T., Z zagadnień handlu wiślanego Warszawy w XVI wieku, „Przegląd Historyczny” 50, 1959, z. 2, s. 297-321.

Czaja R., Kardasz C., Obrót nieruchomościami i kupno renty $w$ miastach pruskich $w X I V-X V w .$, w: Obrót nieruchomościami na ziemiach polskich od średniowiecza do XXI wieku, red. F. Kusiak, Poznań-Wrocław 2008, s. $43-50$.

Czaja R., Kredyt pieniężny w Starym Mieście Toruniu do roku 1410, „Roczniki Dziejów Społecznych i Gospodarczych" 49, 1988, s. 5-19.

Czaja R., Rynek kupna renty w Elblagu w pierwszej połowie XIV wieku, „Zapiski Historyczne” 52, 1987, z. 3, s. 7-37.

Dygo M., Czy w Polsce średniowiecznej byt kryzys gospodarczy?, „Przegląd Historyczny" 80, 1989, s. 752-764.

Gawlas S., Komercjalizacja jako mechanizm europeizacji peryferii na przykładzie Polski, w: Ziemie polskie wobec Zachodu. Studia nad rozwojem średniowiecznej Europy, red. S. Gawlas, Warszawa 2006.

Goff Le J., Sakiewka i życie, tłum. H. Zaremska, Gdańsk 1995.

Goff Le J., Średniowiecze i pieniadze, tłum. B. Baran, Warszawa 2011.

Goliński M., W poszukiwaniu motywów sprzedaży rent nowych - przykład XIV-wiecznej Świdnicy, w: Miasta i mieszczaństwo w Europie środkowowschodniej do połowy XIX w., red. D. Michaluk, K. Mikulski, Toruń 2003, s. 321-332.

Goliński M., Wrocławskie spisy zastawów, długów i mienia żydowskiego z 1453 roku. Studium z historii kredytu i kultury materialnej, Wrocław 2006.

Goliński M., Zmiany $w$ budżecie Wroctawia $w X I V-X V w$. (w świetle bieżacego stanu badań), „Roczniki Dziejów Społecznych i Gospodarczych” 70, 2010, s. $33-62$.

Guriewicz A. J., Kupiec, w: Człowiek średniowiecza, tłum. M. Radożycka-Paoletti, Warszawa-Gdańsk 1996.

Guzowski P., Chtopi i pieniadze na przełomie średniowiecza $i$ czasów nowożytnych, Kraków 2008.

Guzowski P., Kryzys gospodarczy późnego średniowiecza czy kryzys historiografii?, „Roczniki Dziejów Społecznych i Gospodarczych” 68, 2008, s. 173-193.

Guzowski P., Kryzys gospodarczy późnego średniowiecza w najnowszej historiografii angielskiej, w: Przeglad badań nad historia gospodarcza $w$ XXI wieku, red. R. Matera, A. Pieczewski, Łódź 2011, s. 235-246.

Janosz-Biskupowa I., Materiaty do dziejów lichwy w Prusach Krzyżackich w pot. XV wieku, „Studia i Materiały do Dziejów Wielkopolski i Pomorza” 4, 1958, z. 1, s. 355-372.

Jelicz A., Życie codzienne w średniowiecznym Krakowie, Warszawa 1966. 
Karczewska J., Stosunki kredytowe na terytorium Kujaw i wschodniej Wielkopolski $w$ XV wieku, w: Rynki lokalne i regionalne $w X V-X V I I I$ wieku, red. P. Guzowski, K. Boroda, Białystok-Kraków 2013, s. 9-18.

Kardasz C., Rady miast nadbattyckich na rynku renty $w$ XIV i pierwszej połowie XVw., „Roczniki Dziejów Społecznych i Gospodarczych” 70, 2010, s. 113-145.

Kardasz C., Rynek kredytu pieniężnego $w$ miastach południowego pobrzeża Battyku w późnym średniowieczu (Greifswald, Gdańsk, Elblag, Toruń, Rewel), Torun 2013.

Kardasz C., Rynek kupna renty w Elblagu w latach 1361-1417, „Komunikaty Mazursko-Warmińskie” 261, 2008, nr 3, s. 299-318.

Koczorowska-Pielińska E., Liczebność $i$ specjalizacja rzemiosła $w$ Starej $i$ Nowej Warszawie w latach 1417-1526, „Rocznik Warszawski” 11, 1972, s. 5-22.

Koczorowska-Pielińska E., Paśnicy $i$ szewcy $w$ Starej $i$ Nowej Warszawie w latach 1416-1526, „Rocznik Warszawski” 14, 1976, s. 83-113.

Koczorowska-Pielińska E., Przyjęcia do prawa miejskiego miasta Nowej Warszawy w latach 1477-1525, „Rocznik Warszawski” 9, 1969, s. 261-295.

Koczorowska-Pielińska E., Struktura gospodarczo-społeczna Nowej Warszawy w XV wieku, „Przegląd Historyczny” 49, 1958, z. 2, s. 296-310.

Koczorowska-Pielińska E., Warszawskie rzemiosło artystyczne $i$ budowlane w XV w., Warszawa 1959.

Kopiński K., Gospodarcze i społeczne kontakty Torunia z Wrocławiem w późnym średniowieczu, Toruń 2005.

Kubiak S., Monety $i$ stosunki monetarne $w$ Prusach Królewskich $w 2$ połowie XV wieku, Wrocław 1986.

Lesiński B., Kupno renty w średniowiecznej Polsce, Poznań 1966.

Łozowski P., Aktywność gospodarcza kupców i rzemieślników w Starej Warszawie pierwszej połowy XV stulecia, „Almanach Warszawy” 8, 2015, s. 23-46.

Łozowski P., Demografia rodziny mieszczańskiej $w$ Starej Warszawie $w$ pierwszej połowie XV wieku, „Przeszłość Demograficzna Polski” 32, 2013, nr 4, s. $1-18$.

Łozowski P., Pieniadze bogaczy, czyli obce monety w Starej Warszawie pierwszej połowy XV stulecia, w: Moneta czasów kryzysu - moneta czasów pomyślności, red. B. Paszkiewicz, Nowa Sól 2015, s. 153-183.

Łydkowska-Sowina U., Ruch kredytowy w późnośredniowiecznym Sieradzu pożyczki pieniężne, w: Szkice z dziejów materialnego bytowania społeczeństwa polskiego, red. M. Dembińska, Wrocław 1989, s. 119-135.

Małowist M., Podstawy gospodarcze przywrócenia jedności państwowej Pomorza Gdańskiego z Polska w XVw., „Przegląd Historyczny” 45, 1954, z. 2-3, s. $141-187$.

Małowist M., Zagadnienie kryzysu feudalizmu $w$ XIV $i$ XV wieku $w$ świetle najnowszych badań, „Kwartalnik Historyczny” 60, 1953, s. 86-104.

Morawski Z., Ziemia, urzędy, pieniadze. Finanse szlachty tęczyckiej $w$ końcu XIV i pierwszej połowie XV wieku, Warszawa 1993.

Myśliwski G., Wrocław w przestrzeni gospodarczej Europy (XIII-XV wiek). Centrum czy peryferie?, Wrocław 2009. 
Nightingale P., Gold, credit, and mortality: distinguishing deflationary pressures on the late medieval English economy, „Economic History Review” 63, 2010, nr 4, s. 1081-1104.

Olendzki K., Moralność $i$ kredyt. Kontrakt kupna-sprzedaży w traktatach uczonych środkowoeuropejskich z przełomu XIV $i$ XV wieku, „Roczniki Dziejów Społecznych i Gospodarczych” 56/57, 1996/1997, s. 29-67.

Postan M., Medieval Trade and Finance, Cambridge 1973.

Postan M., The Medieval economy and Society: An Economic History of Britain 1100-1500, Cambridge 1972.

Roover de R., Money, Banking And Credit in Medieval Bruges, Cambridge 1948.

Russocki S., Uwagi o polityce targowej ksiażat mazowieckich w XIV i XV w., „Przegląd Historyczny” 51, 1960, z. 2, s. 275-284.

Rutkowski A., Kredyt żydowski na rynku lokalnym Warszawy w pierwszej połowie XV wieku, „Przegląd Historyczny” 70, 1979, z. 2, s. 267-284.

Rutkowski A., Warszawski rynek kredytowy (zasieg i charakterystyka), w: Warszawa Średniowieczna, red. A. Gieysztor, z. 2, Warszawa 1974, s. 69-81.

Sałański M., Rzemieślnicy, kupcy, kramarze. Przyczynek do rozwoju Warszawy i przedsiębiorczości jej mieszkańców od XIV w. do I połowy XVI w., w: $Z$ dziejów Warszawy. Przedsiębiorczość, red. K. Wagner, Warszawa 2013, s. $9-25$.

Samsonowicz H., Badania nad kapitałem mieszczańskim Gdańska w II połowie XV wieku, Warszawa 1960.

Samsonowicz H., Local credit in mediaeval Poland, „Studia Historiae Oeconomicae" 21, 1994, s. 51-57.

Samsonowicz H., Przemiany osi drożnych w Polsce późnego średniowiecza, „Przegląd Historyczny” 64, 1973, z. 4, s. 697-716.

Samsonowicz H., Studia nad renta miejska $w$ Prusach $w$ XV wieku, „Zapiski Historyczne" 25, 1960, z. 2, s. 35-57.

Samsonowicz H., Średniowieczne ksiegi sqdowe matych miast $w$ Polsce, w: Homines et societas. Czasy Piastów i Jagiellonów, red. T. Jasiński, T. Jurek, J. M. Piskorski, Poznań 1997, s. 477-484.

Samsonowicz H., Warszawa jako węzet komunikacyjny w dawnej Polsce, „Kronika Warszawy” 9, 1978, nr 3, s. 5-12.

Samsonowicz H., Warszawa w handlu średniowiecznym, w: Warszawa średniowieczna, red. A. Gieysztor, z. 2, Warszawa 1972, s. 9-31.

Samsonowicz H., Życie miasta średniowiecznego, Poznań 2001.

Sieradzan W., Sasiedztwo mazowiecko-krzyżackie w okresie przemian politycznych w Europie Środkowo-Wschodniej w latach 1411-1466, Torun 1999.

Spufford P., Money and its use in medieval Europe, Cambridge 1988.

Szacherska M., Wójtowie dziedziczni Starej Warszawy w XV i XVI wieku, w: Społeczeństwo Polski średniowiecznej. Zbiór studiów, t. 1, Warszawa 1981, s. $291-346$.

Tandecki J., Rachunkowość $i$ ksiegi rachunkowe miast pruskich $w$ średniowieczu. Wstęp do problematyki, „Roczniki Dziejów Społecznych i Gospodarczych" 70, 2010, s. 19-29. 
Tandecki J., Średniowieczne księgi wielkich miast pruskich jako źródta historyczne $i$ zabytki kultury mieszczańskiej (organizacja władz, zachowane archiwalia, działalność kancelarii), Warszawa-Torun 1990.

Ungeheuer M., Stosunki kredytowe w ziemi przemyskiej w potowie XV wieku, Lwów 1929.

Urbański M., Niektóre problemy ruchu kredytowego w ziemi sanockiej $w X V w$., „Przegląd Historyczny” 70, 1979, z. 4, s. 627-651.

Wawrzyńczyk A., Rola Warszawy $w$ handlu $z W$. Ks. Litewskim i Rosja w XVI w., „Kwartalnik Historyczny” 63, 1956, z. 2, s. 3-26.

Wyrozumski J., Czy późnośredniowieczny kryzys feudalizmu dotknat Polskę?, w: Homines et societas. Czasy Piastów i Jagiellonów, red. T. Jasiński, T. Jurek, J.M. Piskorski, Poznań 1997, s. 103-113.

Zanden van J. L., Zuijderduij J., Moor de T., Small is beautifull: the efficiency of credit markets in the late medieval Holland, „European Review of Economic History" 16, 2012, s. 3-22.

Zuijderduij J., Medieval Capital Markets. Markets for Renten, State Formation and Private Investment in Holland (1300-1550), Leiden-Boston 2009. Żabiński Z., Systemy pieniężne na ziemiach polskich, Wrocław 1981.

Piotr Łozowski

Loan market structure in old Warsaw in the years 1427-1453 (Summary)

The paper presents the results of the analysis of the loan market in Old Warsaw in the second quarter of the $15^{\text {th }}$ century. The research is based in the oldest of the preserved municipal court records from the years 1427-1453, which contain 464 entries concerning loans. The analysis also encompasses such elements as the frequency of the entries, their value, duration of agreements, seasonality of entries, functioning of the instalment system, and types of collateral. The results of the study indicate a steady development of Warsaw's loan market, with the number of entries doubling and their value growing eight-fold starting from the second half of the 1430s. Among the trends noted in the research there is also advancing activisation of commoners and patricians alike, with more and more people participating in loan transactions listed in municipal records.

In general, the Old Warsaw market was based on relatively small (median: two kopa) and short-term (average time: 7 months) loans, which reflects primarily its consumption-oriented and expedient character and, at the same time, little interest of burghers in long-time investment. The analysis of the instalment system shows that cives were able to put aside funds to cover $37 \%$ of the loan's value over a quarter of a year, which, together with short loan terms, seems to reflect good economic condition of the inhabitants of Warsaw in Late Middle Ages. Apart from the record entry itself, half of all agreements 
(49\%) were accompanied with an additional collateral - most frequently (71\%) taking the form of a pledge of real property (houses, gardens, land, breweries), with the creditor hardly ever requiring a guarantee or imposing financial penalty in case of non-payment. The analysis of the dates of taking out and paying off loans shows that people were most in need of money in the "hunger gap," spring and autumn, while agreements were usually settled during several annual fairs (April, June, October, and during festi Nativitatis Christi). In view of significant gaps in comparative literature on the subject of loan markets in the Polish territory in Late Middle Ages, historians are urged to pay more attention to the application and academic value of the relatively wellpreserved clerical patrimony in the form of municipal court records.

Piotr Lozowski - historyk, mediewista, doktorant w Instytucie Historii i Nauk Politycznych UwB. Główny obszar zainteresowań badawczych obejmuje historię społeczno-gospodarczą miast epoki późnego średniowiecza; przygotowuje rozprawę doktorska podejmująca tematykę funkcjonowania rodziny w przestrzeni gospodarczej Starej i Nowej Warszawy w XV i początkach XVI w. E-mail: petruslozowski@gmail.com. 